\title{
Benthic foraminiferal Mn / Ca ratios reflect microhabitat preferences
}

\author{
Karoliina A. Koho ${ }^{1,2,3}$, Lennart J. de Nooijer ${ }^{1}$, Christophe Fontanier ${ }^{4,5,6}$, Takashi Toyofuku ${ }^{7}$, Kazumasa Oguri ${ }^{7}$, \\ Hiroshi Kitazato $^{7,8}$, and Gert-Jan Reichart ${ }^{1,3}$ \\ ${ }^{1}$ Department of Ocean Systems, NIOZ-Royal Netherlands Institute for Sea Research and Utrecht University, \\ Den Burg, the Netherlands \\ ${ }^{2}$ Department of Environmental Sciences, P.O. Box 65 (Viikinkaari 1), 00014 University of Helsinki, Helsinki, Finland \\ ${ }^{3}$ Department of Earth Sciences - Geochemistry, Faculty of Geosciences, Utrecht University, P.O. Box 80.021, \\ 3508 TA Utrecht, the Netherlands \\ ${ }^{4}$ Ifremer, Géosciences marines, Z.I. Pointe du Diable CS10070, 29280 Plouzané, France \\ ${ }^{5}$ Université of Bordeaux, Environnements et Paléo-environnements Océaniques et Continentaux, UMR 5805, \\ 33600 Talence, France \\ ${ }^{6}$ Laboratoire de planétologie et de géodynamique - bio-indicateurs actuels et fossiles, Université of Angers, 49035 Angers, \\ France \\ ${ }^{7}$ Japan Agency for Marine-Earth Science and Technology (JAMSTEC), 2-15 Natsushima-cho, Yokosuka, 237-0061, Japan \\ ${ }^{8}$ Tokyo University of Marine Science and Technology, 4-5-7 Konan, Minato-ku 108-8477, Tokyo, Japan
}

Correspondence to: Karoliina A. Koho (karoliina.koho@helsinki.fi)

Received: 16 December 2016 - Discussion started: 12 January 2017

Revised: 27 April 2017 - Accepted: 19 May 2017 - Published: 22 June 2017

\begin{abstract}
The $\mathrm{Mn} / \mathrm{Ca}$ of calcium carbonate tests of living (rose-Bengal-stained) benthic foraminifera (Elphidium batialis, Uvigerina spp., Bolivina spissa, Nonionellina labradorica and Chilostomellina fimbriata) were determined in relation to pore water manganese $(\mathrm{Mn})$ concentrations for the first time along a bottom water oxygen gradient across the continental slope along the NE Japan margin (western Pacific). The local bottom water oxygen (BWO) gradient differs from previous field study sites focusing on foraminiferal $\mathrm{Mn} / \mathrm{Ca}$ and redox chemistry, therefore allowing further resolution of previously observed trends. The $\mathrm{Mn} / \mathrm{Ca}$ ratios were analysed using laser ablation inductively coupled plasma-mass spectrometer (ICP-MS), allowing singlechamber determination of $\mathrm{Mn} / \mathrm{Ca}$. The incorporation of $\mathrm{Mn}$ into the carbonate tests reflects environmental conditions and is not influenced by ontogeny. The inter-species variability in $\mathrm{Mn} / \mathrm{Ca}$ reflected foraminiferal in-sediment habitat preferences and associated pore water chemistry but also showed large interspecific differences in Mn partitioning. At each station, $\mathrm{Mn} / \mathrm{Ca}$ ratios were always lower in the shallow infaunal E. batialis, occupying relatively oxygenated sediments,
\end{abstract}

compared to intermediate infaunal species, Uvigerina spp. and B. spissa, which were typically found at greater depth, under more reducing conditions. The highest $\mathrm{Mn} / \mathrm{Ca}$ was always recorded by the deep infaunal species $N$. labradorica and $C$. fimbriata. Our results suggest that although partitioning differs, $\mathrm{Mn} / \mathrm{Ca}$ ratios in the intermediate infaunal taxa are promising tools for palaeoceanographic reconstructions as their microhabitat exposes them to higher variability in pore water Mn, thereby making them relatively sensitive recorders of redox conditions and/or bottom water oxygenation.

\section{Introduction}

Benthic foraminifera, single-celled, testate eukaryotes, are common proxies used in palaeoceanographic studies. Many species make a shell, or a test, of calcium carbonate that has a high preservation potential. The chemistry of the carbonate test (i.e. its isotopic and elemental composition) reflects various physical and chemical conditions of the 
calcification environment, thereby allowing the reconstruction of past environmental and climatic conditions. One of the most commonly applied geochemical foraminifera-based proxies is the $\mathrm{Mg} / \mathrm{Ca}$ ratio of the test carbonate, which has been shown to primarily reflect seawater temperatures (e.g. Nürnberg et al., 1996; Elderfield et al., 2006). Other elemental ratios, such as $\mathrm{B} / \mathrm{Ca}$ and $\mathrm{U} / \mathrm{Ca}$, have been shown to reflect carbonate chemistry (e.g. Yu and Elderfield, 2007; Yu et al., 2010; Keul et al., 2013). Previous studies have also highlighted the potential of reconstructing bottom water oxygenation (BWO) and/or sediment redox chemistry, using $\mathrm{Mn} / \mathrm{Ca}$ ratios in benthic foraminifera (Reichart et al., 2003; Glock et al., 2012; Groeneveld and Filipsson, 2013; Koho et al., 2015; McKay et al., 2015). The relationship between $\mathrm{Mn}$ incorporation into foraminiferal test carbonate and oxygenation is based on the combination of Mn availability and redox chemistry, which is typically linked to BWO. Under oxic conditions $\mathrm{Mn}$ is present in the form of solid (hydr)oxides, i.e $\mathrm{MnO}_{2}$ or $\mathrm{MnOOH}$, on coatings on sediment particles (e.g. Finney et al., 1988). Therefore, foraminifera calcifying under oxic condition are likely to incorporate no, or very low amounts of Mn (Koho et al., 2015). In contrast, in the absence of oxygen the solid Mn (hydr)oxides are reduced to aqueous $\mathrm{Mn}^{2+}$ (Froelich et al., 1979), subsequently leading to the build-up of bioavailable $\mathrm{Mn}^{2+}$ in pore water. Foraminifera calcifying under such conditions are expected to show elevated $\mathrm{Mn} / \mathrm{Ca}$ ratios, the concentration depending on the actual in situ aqueous Mn concentrations (Munsel et al., 2010). Exceptions are environments such as oxygen minimum zones, where bottom waters have been oxygendeprived for extended periods. In such cases, aqueous $\mathrm{Mn}^{2+}$ has diffused upwards and was released into the overlying water, leaving pore waters (and sediments) depleted in $\mathrm{Mn}^{2+}$ (e.g. Van der Weijden, 1998; Law et al., 2009). In such settings, foraminiferal test calcite is expected to contain no $\mathrm{Mn}$ (Koho et al., 2015). In sediments, where bottom waters and surficial sediments are oxygenated and deeper sediments are anoxic, and hence $\mathrm{Mn}$ is retained in sediments, the incorporation of $\mathrm{Mn}$ in different species of foraminifera is expected to depend on the species-specific in-sediment living depth.

Benthic foraminifera are traditionally divided into four categories based on their microhabitat: epifauna and shallow, intermediate and deep infauna (Corliss, 1985; Jorissen et al., 1995). This depth distribution is tightly controlled by species-specific responses to environmental redox chemistry and food supply (e.g. Jorissen et al., 1995; Koho et al., 2008; Koho and Piña-Ochoa 2012). Epi- and infauna, living above the sediment-water interface and in surficial sediments, respectively, are typically found under oxic conditions, with increasing living depth corresponding to increasing oxygen depletion and redox stress (e.g. Koho et al., 2008; Koho and Piña-Ochoa, 2012). Therefore, the test chemistry of species with different microhabitat preferences, i.e. living and/or calcifying at different sediment depths with varying $\mathrm{Mn}$ redox chemistry, is expected to display different $\mathrm{Mn} / \mathrm{Ca}$.
This was confirmed in a study of Koho et al. (2015), showing that shallow infaunal species consistently had lower Mn / Ca ratios than species living at the same location but found deeper in the sediment. This resulted in a conceptual model linking bottom water oxygenation, organic matter supply and microhabitat effects (Koho et al., 2015). However, this model is currently based on a limited set of oceanic conditions and theoretical considerations.

Here we present $\mathrm{Mn} / \mathrm{Ca}$ ratios in benthic foraminifera with various microhabitat preferences collected from a depth transect across a dysoxic-to-oxic zone (BWO always $\geq 33 \mu \mathrm{mol} \mathrm{L}^{-1}$ ) in northern Japan. The incorporation of Mn into foraminiferal test carbonate is evaluated in the context of microhabitat distributions and foraminiferal ecology, which have been described previously (Fontanier et al., 2014) for this area, and compared to measured bottom and pore water chemistry.

\section{Materials and methods}

\subsection{Study area}

The sampled transect is located at the continental slope of NE Japan, off Hachinohe (Fig. 1). Surface waters in the area are dominated by three major currents: the Tsugaru Warm Current, the Kuroshio Current and the Oyashio Current. The convergence of these current systems results in a number of hydrological fronts sustaining high productivity in this area (Saino et al., 1998; Itou et al., 2000). Below $200 \mathrm{~m}$ water depth, the North Pacific Intermediate Water (NIPW) mixes gradually with saline Deep Pacific Water (DPW), entering this area between a water depth of 800 and $3000 \mathrm{~m}$. The development of a dysoxic water mass approximately between water depths of 700 and $1400 \mathrm{~m}$ is related to both high surface water productivity, resulting in enhanced remineralisation of organic matter and associated oxygen consumption, and poor intermediate water ventilation at depth (Nagata et al., 1992).

\subsection{Sampling}

Sediment samples were collected in August 2011 onboard of R/V Tansei Maru (Atmosphere and Ocean Research Institute, University of Tokyo/JAMSTEC) with a Barnett-type multicorer equipped with eight Plexiglas tubes with an internal diameter of $82 \mathrm{~mm}$ (Barnett et al., 1984). This type of coring device allows the recovery of undisturbed sediments with an intact sediment-water interface. Sediment for faunal analyses was collected over a transect spanning the oxygen minimum zone (OMZ), whereas pore water chemistry was determined from material collected at three selected sites within this transect (Fig. 1, Table 1). Separate cores were collected for pore water and foraminiferal analyses and oxygen profiling; all of these cores were derived from the same multicore cast. In addition to coring, a conductivity-temperature- 

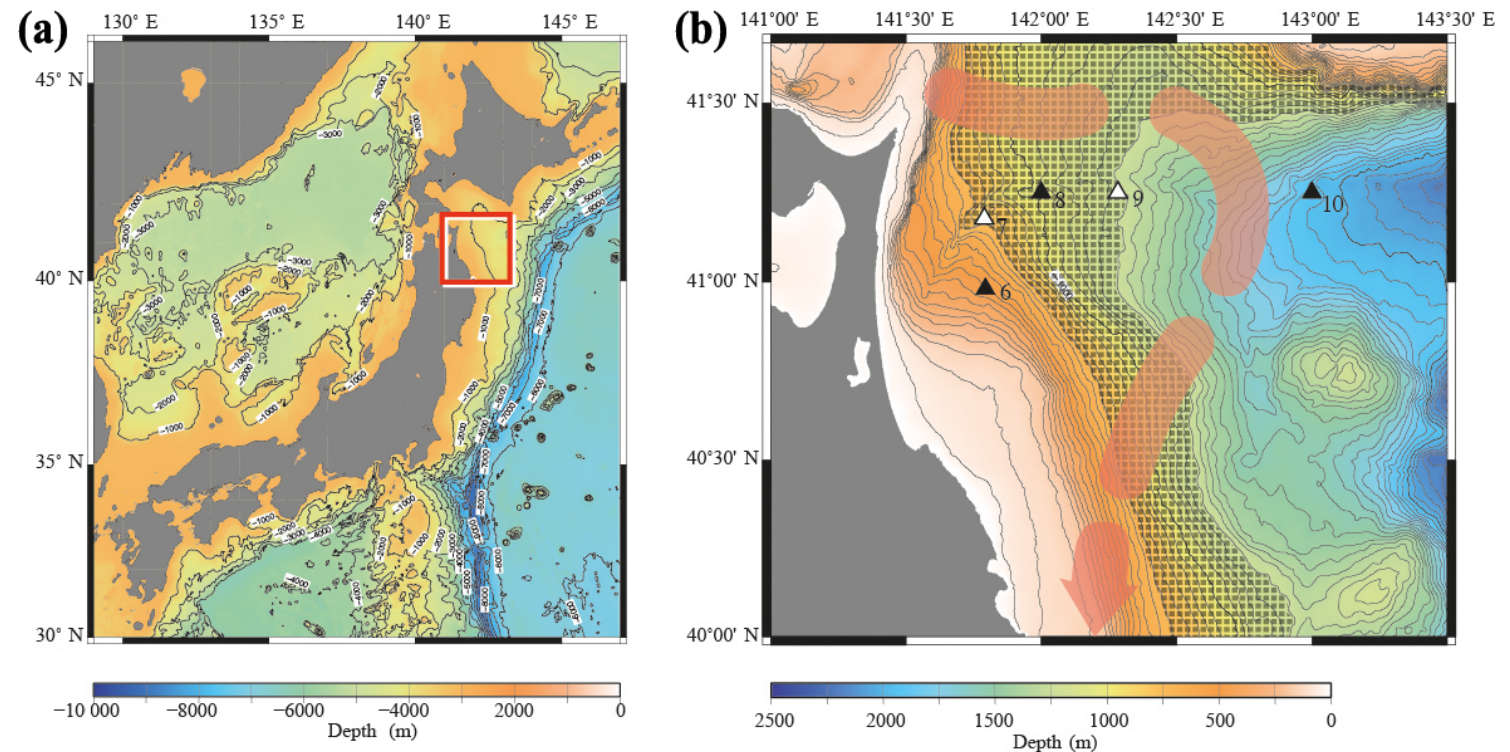

(c)

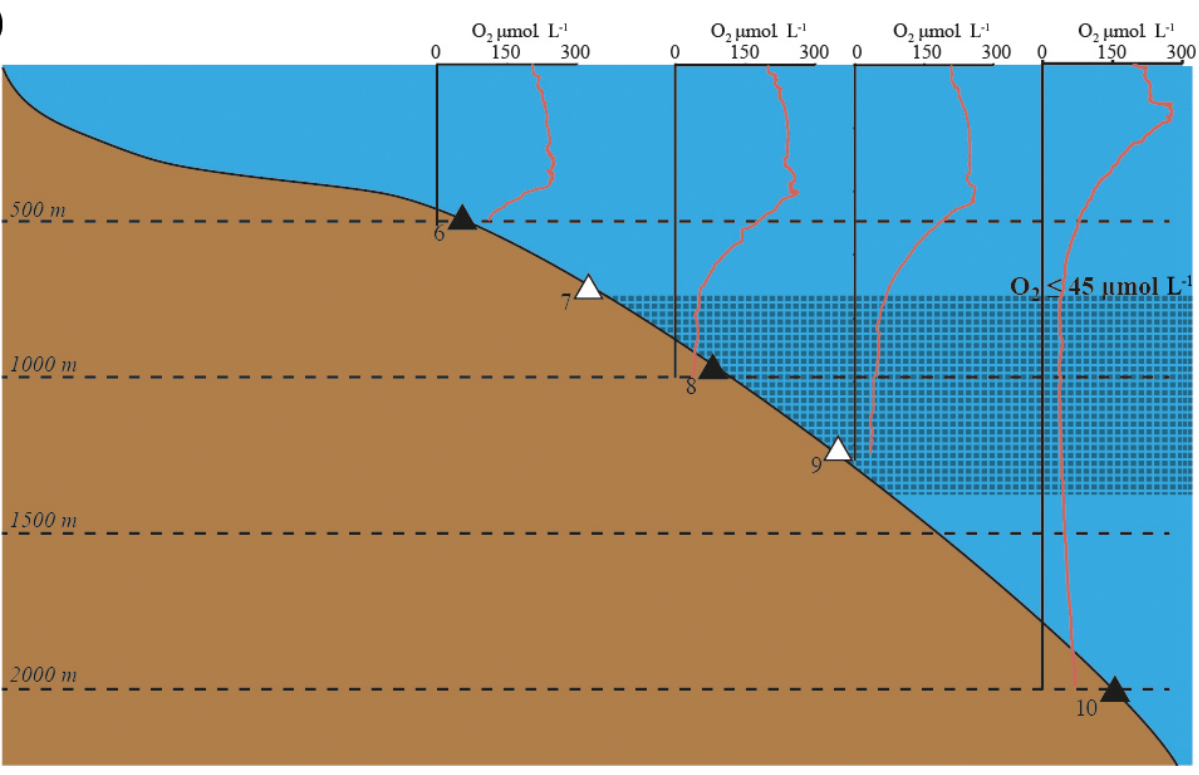

Figure 1. (a) Regional map of the study area. (b) Bathymetric map of the study region, showing the position of the Tsugaru Warm Current (Oguma et al., 2002) and multicore sampling sites. (c) Schematised study transect with water column profiles of dissolved oxygen. The dysoxic water column $\left(\mathrm{O}_{2}<45 \mu \mathrm{mol} \mathrm{L}{ }^{-1}\right)$, located approximately between 750 and $1400 \mathrm{~m}$, is indicated by a grey-square pattern. Black triangles indicate stations where pore water parameters were measured. White triangles are stations where pore water data were not obtained.

depth (CTD) cast (Sea-Bird Electronics, S/N 860; SBE9plus) equipped with an SBE3 thermometer (S/N 4378), SBE4 conductivity sensor (S/N 3307) and SBE43 oxygen sensor (S/N 0781) was taken at every site to record water column properties. The accuracy specifications of the oxygen sensor are typically within $2 \%$ of true value.

\subsection{Pore water analyses}

Immediately upon arrival on board, bottom water samples were taken from overlying multicore water after which the core was transferred via a table with a closely fitted hole into a $\mathrm{N}_{2}$-purged glove bag for sequential slicing (atmospheric $\mathrm{O}_{2}$ within the glove bag never exceeding $1 \%$ ). The core was subsequently sliced down to $20 \mathrm{~cm}$ depth: the first $2 \mathrm{~cm}$ had intervals with a resolution of $0.5 \mathrm{~cm}$; between 2 and $10 \mathrm{~cm}$, samples were taken at $1 \mathrm{~cm}$ intervals; and from $10 \mathrm{~cm}$ down- 
Table 1. Station details including latitude, longitude, water depth and BWO content. In addition sites where pore water and foraminifera were collected are indicated.

\begin{tabular}{lllrrrc}
\hline Station & $\begin{array}{l}\text { Latitude } \\
(\mathrm{N})\end{array}$ & $\begin{array}{l}\text { Longitude } \\
(\mathrm{E})\end{array}$ & $\begin{array}{r}\text { Depth } \\
(\mathrm{m})\end{array}$ & $\begin{array}{r}\text { BWO } \\
\left.(\mu \mathrm{mol} \mathrm{L})^{-1}\right)\end{array}$ & Foraminifera & $\begin{array}{l}\text { Pore } \\
\text { water }\end{array}$ \\
\hline 6 & $40^{\circ} 58.891^{\prime}$ & $141^{\circ} 47.572^{\prime}$ & 496 & 112 & Yes & Yes \\
7 & $41^{\circ} 10.647^{\prime}$ & $141^{\circ} 47.348^{\prime}$ & 760 & 42 & Yes & No \\
8 & $41^{\circ} 15.003^{\prime}$ & $142^{\circ} 00.028^{\prime}$ & 1033 & 36 & Yes & Yes \\
9 & $41^{\circ} 14.982^{\prime}$ & $142^{\circ} 16.969^{\prime}$ & 1249 & 33 & Yes & No \\
10 & $41^{\circ} 14.918^{\prime}$ & $142^{\circ} 59.989^{\prime}$ & 1963 & 70 & Yes & Yes \\
\hline
\end{tabular}

wards, they had $2 \mathrm{~cm}$ intervals. Sediment samples were centrifuged in $50 \mathrm{~mL}$ tubes for $20 \mathrm{~min}$ at $2800 \mathrm{rpm}$. The supernatant was removed and filtered over $0.45 \mu \mathrm{m}$ TeflonTM filters under $\mathrm{N}_{2}$ atmosphere and divided into subsamples for various analyses. The nutrient samples were stored at $-20^{\circ} \mathrm{C}$ until analyses, and back in the laboratory nitrate concentrations were measured with a Bran-Luebbe AA3 autoanalyser, and ammonium was measured spectrophotometrically using phenol-hypochlorite (Helder and De Vries, 1979). Samples for pore water elemental analyses were acidified with Suprapur $\mathrm{HCl} 37 \%$ (10 $\mu \mathrm{L}$ per millilitre of sample) and subsequently stored at $4{ }^{\circ} \mathrm{C}$ until analysis at Utrecht University. Seawater elemental concentrations of ${ }^{55} \mathrm{Mn}$ were measured with an inductively coupled plasma mass spectrometer (ICPMS, ThermoFisher Scientific Element2-XR). Replicate analyses and an in-house standard indicated that the relative error for analyses of pore water element concentrations was generally less than $3 \%$.

\subsection{Oxygen micro-profiles}

The oxygen micro-profiles were recorded in a custom-built incubation chamber, allowing the regulation of temperature and oxygen content of overlaying water, and have been previously published in Fontanier et al. (2014). A brief summary is as follows: upon retrieval on board, one core (from stations 6,8 and 10 only) was immediately subsampled with a piston device made of a $50 \mathrm{~mL}$ syringe and subsequently placed into the incubation chamber filled with bottom water collected with Niskin bottles. Every core was left to stabilise for a minimum of $9 \mathrm{~h}$ while the temperature and oxygen concentrations were kept at in situ conditions. Any fluctuations in the oxygen concentrations were less than $0.5 \mu \mathrm{mol} \mathrm{L}^{-1}$. Afterwards, the oxygen micro-profiles were measured with an OX-50 Unisense microsensor and a motor controller (step size of $100 \mu \mathrm{m})$.

\subsection{Foraminifera: sampling and elemental composition}

The details of benthic foraminiferal processing and analyses are described in Fontanier et al. (2014). In summary, cores for faunal analyses were sliced at $0.5 \mathrm{~cm}$ intervals down to $4 \mathrm{~cm}$, at $1 \mathrm{~cm}$ interval from 4 to $6 \mathrm{~cm}$ depth and at $2 \mathrm{~cm}$ intervals down to $10 \mathrm{~cm}$ depth in sediment. Samples were preserved and stained with rose bengal dissolved in $95 \%$ ethanol $\left(1 \mathrm{~g} \mathrm{~L}^{-1}\right)$. Stained (living) foraminifera in the $>150 \mu \mathrm{m}$ fraction were wet picked, identified and stored on micropalaeontological slides. From the census data of Fontanier et al. (2014), the average living depth (ALD) of selected species was calculated based on the equation in Jorissen et al. (1995).

A few species occurring in high relative abundance and representing various microhabitats were selected for $\mathrm{Mn} / \mathrm{Ca}$ measurements (Table 2). Most of the specimens came from surficial sediments (top $0.5 \mathrm{~cm}$ ), but for some taxa, specimens from deeper sediment intervals were measured additionally (Table 2). Prior to analyses, all foraminifera were thoroughly cleaned to remove sediment contamination (Barker et al., 2003); this was done by placing the foraminifera in Eppendorf tubes and rinsing them three times in ultrapure water $(100 \mu \mathrm{L})$. This was followed by three rinses in methanol $(100 \mu \mathrm{L})$ and finally three more rinses in ultrapure water $(100 \mu \mathrm{L})$. Between the methanol rinses, foraminifera were placed in an ultrasonic bath for approximately $5 \mathrm{~s}$. After these steps, specimens were dried and stored until geochemical analyses.

Trace element content was measured generally on single foraminiferal chambers (Table 2) with two different laser ablation ICP-MS setups, which have been shown to produce comparable foraminiferal elemental / Ca results (de Nooijer et al., 2014). In all cases, shells were ablated from the outside towards the inside (Fig. 2) in He environment, and element ratios were based on averaging measured concentrations during each ablation after selecting the non-contaminated part of the ablation profile, which was recognised by elevated counts of $\mathrm{Al}, \mathrm{Mg}$ and $\mathrm{Mn}$ at the beginning, and occasionally the end, of the ablation profile (Fig. 2). Although all tests were carefully cleaned, test surfaces of foraminifera can still be contaminated with adhered particles containing elevated concentrations of $\mathrm{Mg}$ and $\mathrm{Mn}$ in combination with elevated $\mathrm{Al}$. These parts of the ablation profiles were excluded from further consideration (Fig. 2). Short ablation profiles (generally less than $5 \mathrm{~s}$ ) were excluded from the data, and only longer ablation profiles, typically ranging between 10 and $30 \mathrm{~s}$ in length, were used. 
(a) Elphidium batialis

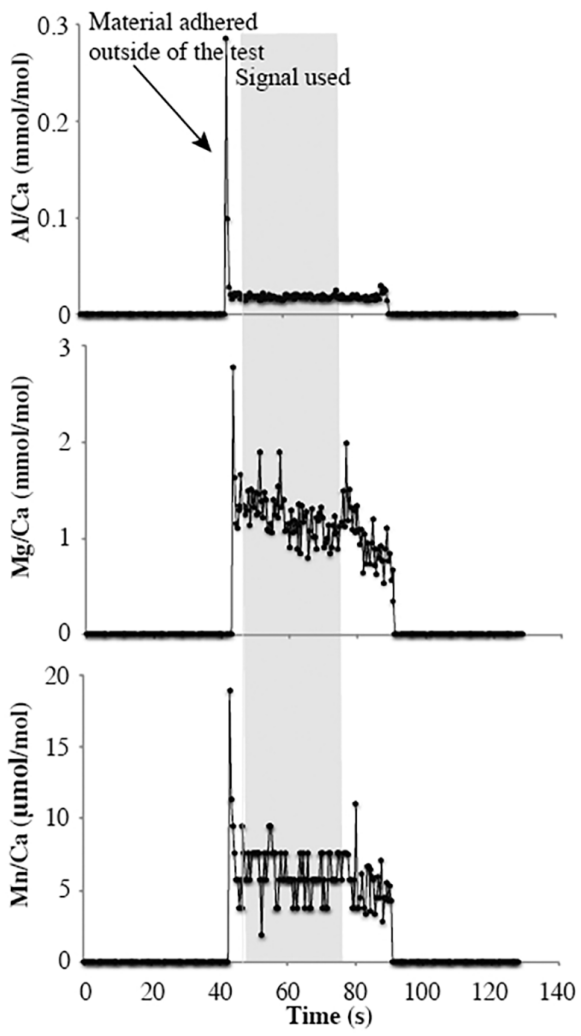

(b) Uvigerina akitaensis

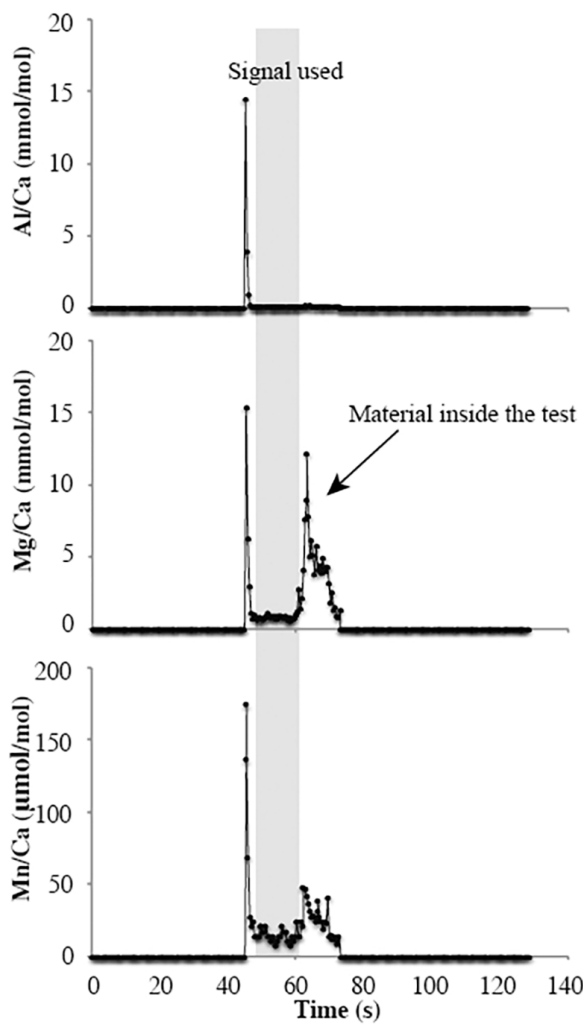

Figure 2. Laser ablation profile for $\mathrm{Al} / \mathrm{Ca}, \mathrm{Mg} / \mathrm{Ca}$ and $\mathrm{Mn} / \mathrm{Ca}$ measured in (a) Elphidium batialis (station $8,0-0.5 \mathrm{~cm}$ depth) and (b) Uvigerina akitaensis (station 7, 0-0.5 cm depth) benthic foraminifera. The selected signal for the elemental composition is indicated by the grey shading. Parts of the profile with elevated surface ratios, especially $\mathrm{Al} / \mathrm{Ca}$, are removed. In addition, the elevated concentrations, following the ablation through the foraminiferal test, are not included in the averaged elemental ratios. Note the different scale bars for elemental ratios.

Measurements carried out at Utrecht University were done with a deep-ultraviolet wavelength laser $(193 \mathrm{~nm})$ using a Lambda Physik excimer system with GeoLas 200Q optics (Reichart et al., 2003). Every ablation lasted approximately $130 \mathrm{~s}$, of which the first $45 \mathrm{~s}$ consisted of background. Ablation craters were circular with a diameter of $80 \mu \mathrm{m}$; the pulse repetition rate was $5 \mathrm{~Hz}$ and the energy density at the sample surface approximately $1 \mathrm{~J} \mathrm{~cm}^{-2}$. Element-to-calcium ratios were quantified using counts for ${ }^{27} \mathrm{Al},{ }^{43} \mathrm{Ca},{ }^{44} \mathrm{Ca},{ }^{24} \mathrm{Mg}$, ${ }^{26} \mathrm{Mg}$ and ${ }^{55} \mathrm{Mn}$ and their relative natural abundances on a sector field ICP-MS (Element2, Thermo Scientific). The cycle length through all masses was $0.64 \mathrm{~s}$. Raw counts were converted to element concentrations, and integration windows were set using the computer program Glitter (developed by the ARC National Key Centre for Geochemical Evolution and Metallogeny of Continents (GEMOC) and CSIRO Exploration and Mining). Calibration was performed against the international NIST SRM 610 glass standard (using concentrations from Jochum et al., 2011) at a higher energy density $\left(5 \mathrm{~J} \mathrm{~cm}^{-2}\right)$, which was ablated twice every $12 \mathrm{sam}$ ples. The calibration of element / calcium ratios in calcium carbonate samples using a NIST glass standard has been demonstrated to be accurate for many elements when using a $193 \mathrm{~nm}$ laser (Hathorne et al., 2008). Switching energy density between carbonate sample and glass standard has been shown not to affect the concentration of the relevant elements (Dueñas-Bohórquez et al., 2010).

Some samples were measured at the Royal NIOZ (Netherlands Institute for Sea Research) using a comparable, but slightly different setup. This configuration consists of an NWR193UC (New Wave Research) laser, containing a dualvolume ablation cell and an ArF excimer laser (Existar) with deep UV $193 \mathrm{~nm}$ wavelength and less than $4 \mathrm{~ns}$ pulse duration, connected to a quadrupole ICP-MS (iCAP-Q, Thermo Scientific). The energy density of the ablation was also set to $1 \mathrm{~J} \mathrm{~cm}^{-2}$, the ablation spot was $60 \mu \mathrm{m}$ in diameter and the repetition rate was $6 \mathrm{~Hz}$ for the foraminiferal samples. Calibration to the NIST610 standard was identical to that performed at Utrecht University. Helium was used as a carrier gas with a flow rate of $0.8 \mathrm{~L} \mathrm{~min}^{-1}$ for cell gas and $0.3 \mathrm{~L} \mathrm{~min}^{-1}$ for cup gas. From the laser chamber to the ICP-MS, the He flow was mixed with $\sim 0.4 \mathrm{~L} \mathrm{~min}^{-1}$ neb- 
uliser Ar and $0.0025 \mathrm{~mL} \mathrm{~min}^{-1} \mathrm{~N}_{2}$. Before measuring the samples, the nebuliser gas, extraction lense, CCT (collision cell technology) focus lense and torch position were automatically tuned for the highest sensitivity to ${ }^{238} \mathrm{U},{ }^{139} \mathrm{La}$, ${ }^{59} \mathrm{Co}$ and low $\mathrm{ThO} / \mathrm{Th}$ ratios (less than $1 \%$ ) by laser ablating NIST SRM 610 glass. Masses monitored included ${ }^{27} \mathrm{Al}$, ${ }^{43} \mathrm{Ca},{ }^{44} \mathrm{Ca},{ }^{24} \mathrm{Mg},{ }^{26} \mathrm{Mg}$ and ${ }^{55} \mathrm{Mn}$. Every ablation lasted approximately $100 \mathrm{~s}$, of which the first $20 \mathrm{~s}$ consisted of a background. The cycle length through all masses was $0,12 \mathrm{~s}$. Intensity data were integrated, background subtracted, standardised internally to ${ }^{43} \mathrm{Ca}$ and calibrated against the NIST SRM 610 signal using Thermo Qtergra software and reference values from Jochum et al. (2011), assuming $40 \% \mathrm{Ca}$ weight for the foraminiferal samples. JCp-1, MACS-3 and an in-house (foraminiferal) calcite standard (NFHS - NIOZ foraminifera house standard) were used for quality control and measured every 10 foraminiferal samples. The relative standard deviation in element / Ca based on multiple measurements on the NFHS is comparable to that of other standards (Mezger et al., 2016). Internal reproducibility of the analyses was all better than $10 \%$, based on the three different carbonate standards.

The resulting $\mathrm{Mn}$ and $\mathrm{Ca}$ concentrations in foraminiferal test carbonate were used to calculate partition coefficients $(D)$ according to the following equation:

$D_{\mathrm{Mn}}=(\mathrm{Mn} / \mathrm{Ca})_{\text {calcite }} /(\mathrm{Mn} / \mathrm{Ca})_{\text {pore water }}$.

\section{Results}

\subsection{Bottom water chemistry and pore water profiles}

The BWO content varied from $112 \mu \mathrm{mol} \mathrm{L}-1$ at station 6 to $33 \mu \mathrm{mol} \mathrm{L}^{-1}$ measured at station 9 (Table 1). Stations 7 and 8 were also bathed in dysoxic $\left(<45 \mu \mathrm{mol} \mathrm{L}^{-1}\right)$ bottom water. These low BWO contents were reflected in the shallow oxygen penetration depths (Fig. 3), measuring less than $5 \mathrm{~mm}$ at all sites and reaching a minimum of less than $2 \mathrm{~mm}$ at station 6.

Pore water chemistry, including dissolved oxygen, nitrate, ammonium and manganese, was measured at sites 6,8 and 10 (Fig. 3). Nitrate concentrations always peaked in the bottom waters (approximately $40 \mu \mathrm{mol} \mathrm{L}^{-1}$ ), implying an influx of nitrate from the overlying water into the sediments. In all cores, nitrate was rapidly depleted within surficial sediments. Only at station 10, a small subsurface peak was noted in nitrate between 2 and $3 \mathrm{~cm}$ depth. The decline in pore water oxygen and nitrate was accompanied with an increase in ammonium, typically reaching close to $100 \mu \mathrm{mol} \mathrm{L}^{-1}$ at $20 \mathrm{~cm}$ depth. However, in the top $5 \mathrm{~cm}$, where most of the foraminifera were located (Fontanier et al., 2014), ammonium concentrations were always below $30 \mu \mathrm{mol} \mathrm{L}-1$.

A subsurface peak was observed in pore water Mn concentrations at all sites, suggesting that manganese reduction was taking place within the sediments. However, at station 6 the Mn concentrations were generally low and did not exceed $1.4 \mu \mathrm{mol} \mathrm{L}{ }^{-1}(0.5-1 \mathrm{~cm}$ depth interval). At station 8 the subsurface peak was somewhat more developed but the concentrations still remained low $\left(\sim 2 \mu \mathrm{mol} \mathrm{L}{ }^{-1}\right)$ : between 0.5 and $1.5 \mathrm{~cm}$ depth in sediment. At station 10, the subsurface manganese front was much broader, extending from 2 to $12 \mathrm{~cm}$ depth with a maximum concentration of $5.0 \mu \mathrm{mol} \mathrm{L}^{-1}$ in the $5-6 \mathrm{~cm}$ depth interval.

\section{2 $\mathrm{Mn}$ / Ca ratios in single foraminiferal chambers}

$\mathrm{Mn} / \mathrm{Ca}$ ratios were measured in multiple foraminiferal chambers, ranging from chambers F-1 and F-2 (penultimate or pre-penultimate) to F-12 and to the umbo in Elphidium batialis. Selected data of single chamber measurements are presented in Fig. 4, showing E. batialis, Uvigerina akitaensis and Bolivina spissa from stations with the highest numbers of specimens measured across a range of chambers. In addition, single specimen measurements, in which four or more chambers were measured, are shown in Supplement Fig. S1. For none of the species, or for individual profiles shown in Fig. S1, was there any trend in $\mathrm{Mn} / \mathrm{Ca}$ ratios with chamber number (Pearson correlation where two-tailed significance was always $>0.05$ ). The statistical data analyses were carried out on all data (see all Mn / Ca data in Table S1 in the Supplement), confirming the absence of a relation between shell size and $\mathrm{Mn} / \mathrm{Ca}$. An example of Nonionellina labradorica is not shown in Fig. 4 as a relatively low number of total measurements $(n=18)$ was performed on this species, and hence statistical tests are not robust. Further, due to test configuration of Chilostomellina fimbriata, only the final chamber (F-0) was analysed, and hence a potential size-related effect could not be determined.

Since no trend was present between $\mathrm{Mn} / \mathrm{Ca}$ and chamber number, all data were combined for interpretation in the following sections.

\subsection{Mn / Ca ratios in test calcite and foraminiferal microhabitat distribution}

Foraminiferal $\mathrm{Mn} / \mathrm{Ca}$ ratios were generally low in $E$. $b a$ tialis, ranging from 0.9 to $33.8 \mu \mathrm{mol} \mathrm{mol}^{-1}$ (Fig. 5). The highest concentrations were measured in $N$. labradorica (ranging from 23.4 to $277.0 \mu \mathrm{mol} \mathrm{mol}^{-1}$ ). E. batialis also showed least variability in measurements per sample with the average standard error of all measurements per station ranging between 0.2 and $7.4 \mu \mathrm{mol} \mathrm{mol}^{-1}$.

Most of the measurements were performed on specimens collected from surface sediments; however, for Uvigerina spp., B. spissa, N. labradorica and C. fimbriata, specimens were also measured from deeper sediment intervals (Fig. 5). However, no statistical correlations were observed between the depths where foraminifera were found and their $\mathrm{Mn} / \mathrm{Ca}$ ratios (Table 3). However, statistical tests with $N$. 


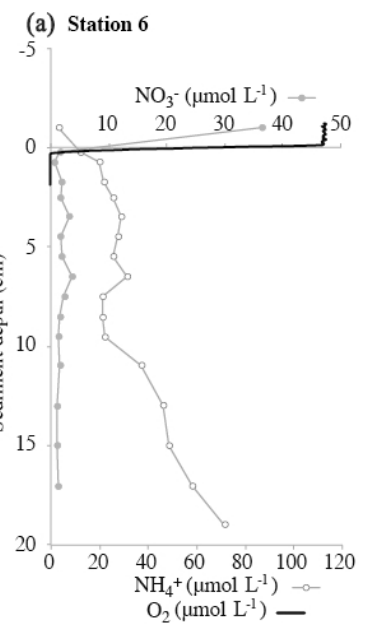

(c) Station 10

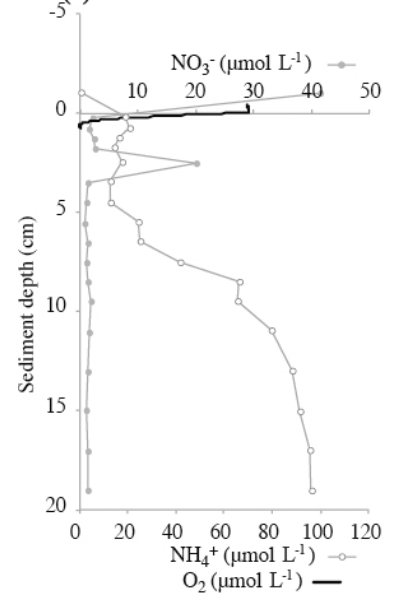

(b) Station 8

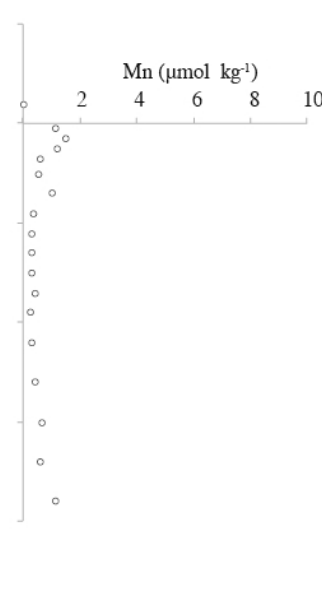

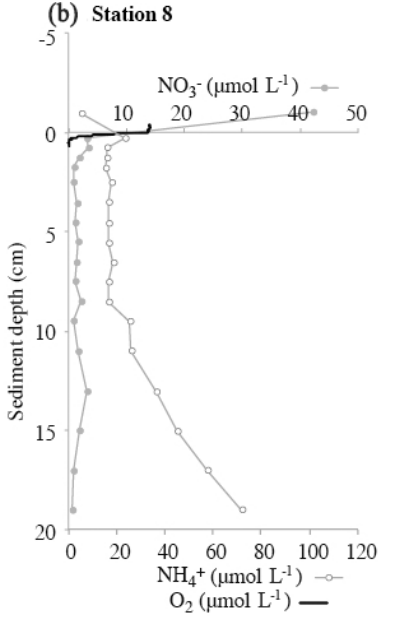

(d) Mn inventory vs. BWo
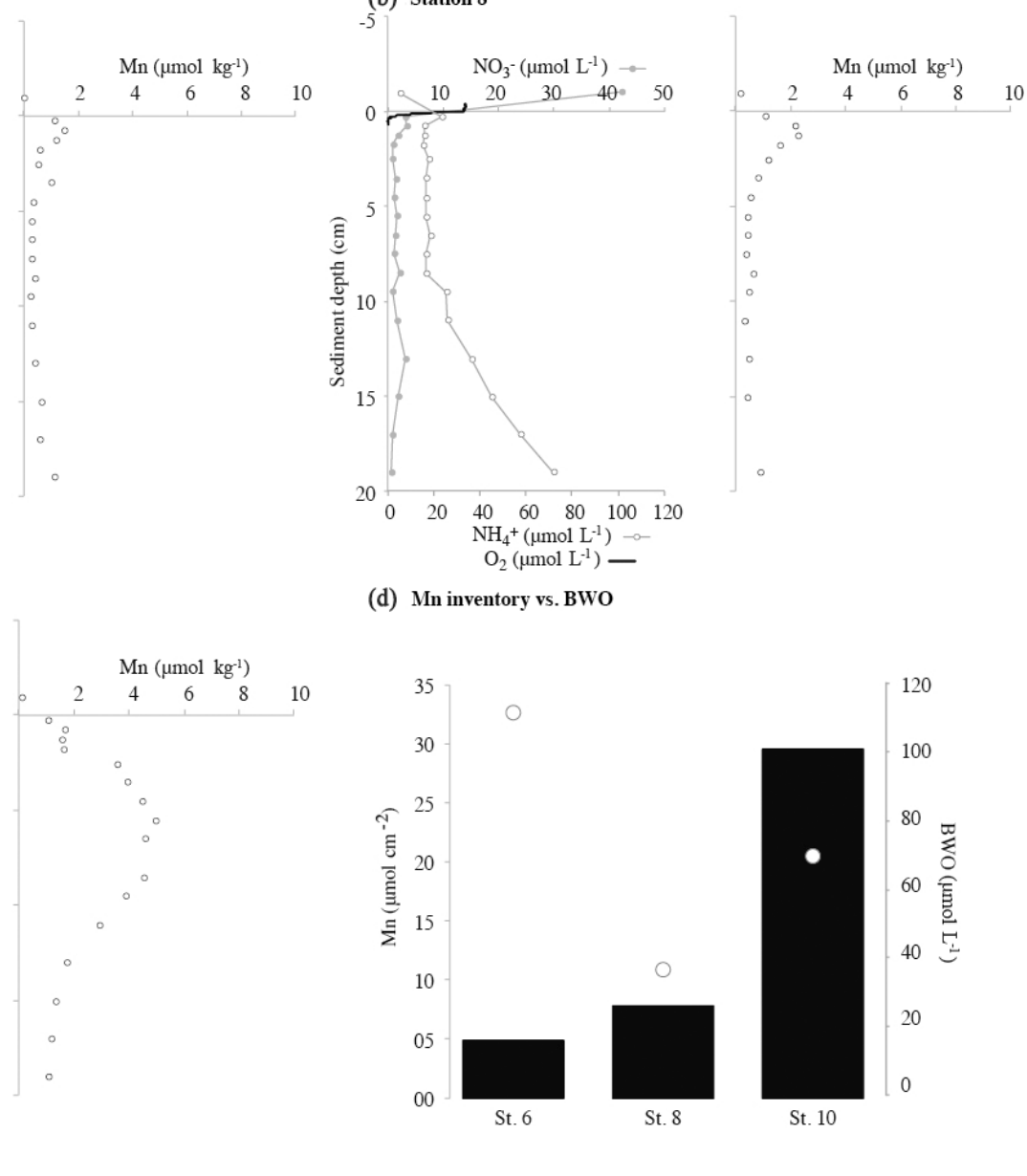
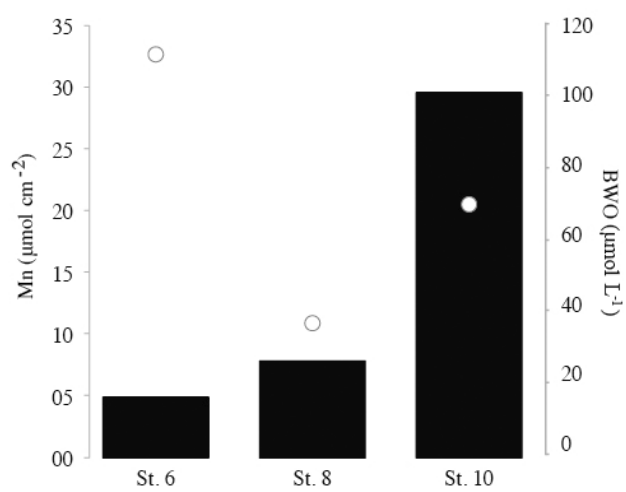

Figure 3. Pore water profiles of dissolved oxygen, nitrate, ammonium and manganese at stations 6 (a), 8 (b) and 10 (c). (d) Pore water manganese inventory in the top $10 \mathrm{~cm}$ of sediment and bottom water oxygen content (white symbols).

Table 2. Total number of laser ablation measurements and number of foraminifera ablated. In addition, the depth intervals of specimens per station are indicated.

\begin{tabular}{|c|c|c|c|c|c|c|c|}
\hline \multirow[t]{2}{*}{ Species } & \multirow[t]{2}{*}{ Measurements } & \multirow[t]{2}{*}{ Specimens } & \multicolumn{5}{|c|}{ Depth intervals of foraminifera $(\mathrm{cm})$} \\
\hline & & & ST 6 & ST7 & ST8 & ST9 & ST10 \\
\hline E. batialis & 65 & 44 & $0-0.5$ & $0-0.5$ & $0-0.5$ & $0-0.5$ & $0-0.5$ \\
\hline Uvigerina spp. & 100 & 66 & $0-0.5$ & $0-0.5$ & $0-0.5$ & $0-0.5$ & $0-0.5 ; 0.5-1 ; 1-1.5$ \\
\hline B. spissa & 79 & 23 & & $0-0.5$ & $0-0.5$ & $0-0.5 ; 0.5-1$ & \\
\hline N. labradorica & 18 & 18 & & $0-0.5$ & $0-0.5 ; 2-2.5 ; 4-5$ & & $0-0.5$ \\
\hline C. fimbriata & 15 & 15 & & $0-0.5$ & $4-5$ & $1-1.5 ; 3-3.5$ & \\
\hline
\end{tabular}

labradorica and $C$. fimbriata are of limited value due to the low total number of specimens measured at these sites.

The average living depth of all species analysed was calculated after Jorissen et al. (1995). The shallowest living depth was noted for E. batialis and was generally encountered in the upper $1 \mathrm{~cm}$ of the cores (Fig. 6). At site 10, a few isolated specimens were found deeper in sediment, resulting in an overall average living depth of $1.2 \mathrm{~cm}$. Uvigerina spp. (U. cf. graciliformis - station 6; U. akitaensis - stations 7, 8 and 9) was found at slightly greater depth, with an ALD ranging from $1.0 \mathrm{~cm}$ at station 9 to $2.1 \mathrm{~cm}$ at station 7. B. spissa was consistently found living at greater depth than Uvigerina spp. with an average living depth close to $2 \mathrm{~cm}$. Of the two deep-living taxa, the average living depth of $C$. fimbriata was around $5 \mathrm{~cm}$ depth, whereas $N$. labradorica was centred at $4 \mathrm{~cm}$ depth in sediment, except at station 7 where the ALDs 

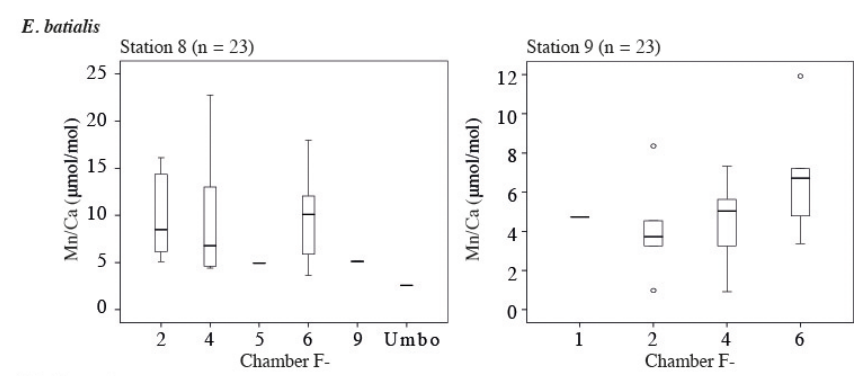

U. akitaensis
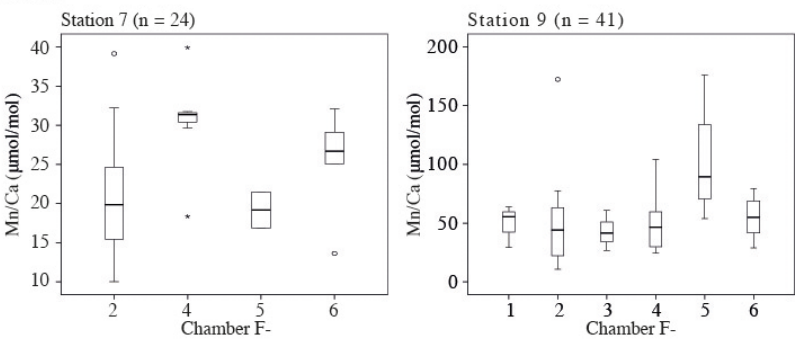

B. spissa
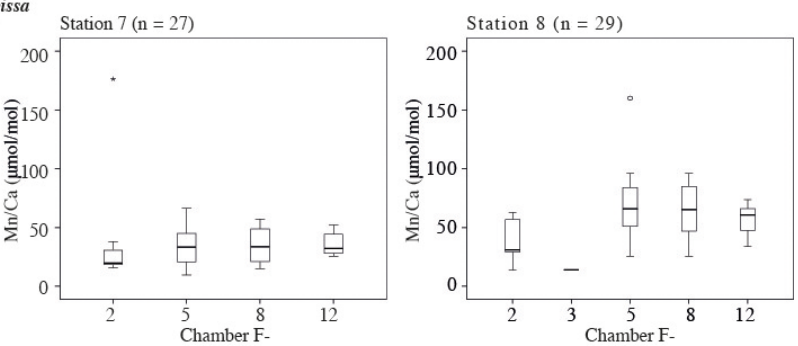

Figure 4. Box plots showing chamber-to-chamber variability in $\mathrm{Mn} / \mathrm{Ca}$. Error bars display the full range of data variation (data within 1.5 interquartile (IQ) range ). Data outliers are represented with a white circle (between 1.5 and 3 IQ range), and extreme data outliers are indicated by an asterisk (above 3 IQ range).

Table 3. Pearson correlation coefficients and significance values for $\mathrm{Mn} / \mathrm{Ca}$ ratios of Uvigerina spp. (St 9), B. spissa (St 9). $N$. labradorica (St 8 ) and $C$. fimbriata $($ St 9$)$ versus sediment depth from where foraminifera were collected.

\begin{tabular}{lrrr}
\hline Species & $\begin{array}{r}\text { Pearson } \\
\text { correlation }\end{array}$ & Significance & $N$ \\
\hline Uvigerina spp. & 0.267 & 0.91 & 41 \\
B. spissa & 0.017 & 0.937 & 23 \\
N. labradorica & 0.512 & 0.159 & 9 \\
C. fimbriata & 0.404 & 0.247 & 10 \\
\hline
\end{tabular}

of these species were 2.9 and $2.3 \mathrm{~cm}$, respectively. Overall, a systematic distribution of foraminiferal microhabitats was observed with the shallow infaunal microhabitat represented by $E$. batialis. An intermediate infaunal habitat was occupied by Uvigerina spp. and B. spissa, and the deep infaunal habitat was inhabited by $N$. labradorica and C. fimbriata.

Systematic changes were noted in $\mathrm{Mn} / \mathrm{Ca}$ ratios with respect to foraminiferal microhabitat (Fig. 6). Lowest Mn / Ca values were found in the shallow infaunal E. batialis, fol- lowed by intermediate infaunal species Uvigerina spp. At stations 7, 9 and 10, foraminiferal $\mathrm{Mn} / \mathrm{Ca}$ rations continued to increase with increasing habitat depth or their ALD. However, an exception was noted at station 8 , where the highest $\mathrm{Mn} / \mathrm{Ca}$ was recorded for the deep infaunal species $N$. labradorica and not in the deeper-living $C$. fimbriata.

Despite the clear pattern between foraminiferal $\mathrm{Mn} / \mathrm{Ca}$ with respect to microhabitat distribution, the $\mathrm{Mn} / \mathrm{Ca}$ concentrations from the average living depth do not exactly match the pore water profiles (Fig. 6), although direct comparisons are not possible for stations 7 and 9. At station 8 , for example, the peak in the pore water $\mathrm{Mn} / \mathrm{Ca}$ is found at a depth of approximately $1 \mathrm{~cm}$, whereas the highest foraminiferal $\mathrm{Mn} / \mathrm{Ca}$ ratios are found in N. labrador$i c a$, with an ALD of $4.0 \mathrm{~cm}$. At station 10, however, where pore water Mn content is clearly increasing with sediment depth, foraminiferal $\mathrm{Mn} / \mathrm{Ca}$ ratios show a similar trend. At station 6, where pore water Mn content is generally low, foraminiferal $\mathrm{Mn} / \mathrm{Ca}$ ratios are also low.

Partitioning coefficients of $\mathrm{Mn}\left(D_{\mathrm{Mn}}\right)$ for each taxon were calculated for stations 6,8 and 10 , where pore water data were available (Fig. 7, Table S1). Calculations were based on pore water Mn concentrations at the ALD of each species and their average $\mathrm{Mn} / \mathrm{Ca}$ ratios. The $D_{\mathrm{Mn}}$ of E. batialis was very low, ranging from 0.02 at station 10 to 0.03 at station 8 . The $D_{\mathrm{Mn}}$ of Uvigerina spp. was slightly higher, ranging from 0.18 to 0.56 ; and that of $B$. spissa was similar, with an average $D_{\mathrm{Mn}}$ of 0.36 . The deep infaunal taxa generally had higher $D_{\mathrm{Mn}}$, with a coefficient for $N$. labradorica of 1.24 and of 1.77 for $C$. fimbriata. However, at station 10 the calculated $D_{\mathrm{Mn}}$ for $N$. labradorica was also low (0.18).

\subsection{Foraminiferal Mn / Ca ratios along the study transect}

The $\mathrm{Mn}$ / Ca ratios of Uvigerina spp. and B. spissa increased with water depth (Fig. 8). Both of these trends were statistically robust with Pearson correlation coefficients of 0.43 $(p<0.01 ; n=100)$ and $0.65(p<0.01 ; n=79)$ for Uvigerina spp. and $B$. spissa, respectively. Average $\mathrm{Mn} / \mathrm{Ca}$ ratios of $E$. batialis on the other hand declined slightly along the study transect (Pearson correlation coefficient -0.64 $p<0.01 n=65$ ), whereas no trends in $\mathrm{Mn} / \mathrm{Ca}$ with water depth were found for $N$. labradorica or C. fimbriata.

Only the $\mathrm{Mn} / \mathrm{Ca}$ ratios of $B$. spissa correlated significantly with measured BWO content (Pearson correlation coefficient $-0.59 ; p<0,01 ; n=79)$. For Uvigerina spp. the highest $\mathrm{Mn} / \mathrm{Ca}$ ratios coincided with the lowest BWO content. For none of the other taxa were systematic, statistically significant trends observed between BWO content and $\mathrm{Mn} / \mathrm{Ca}$. 

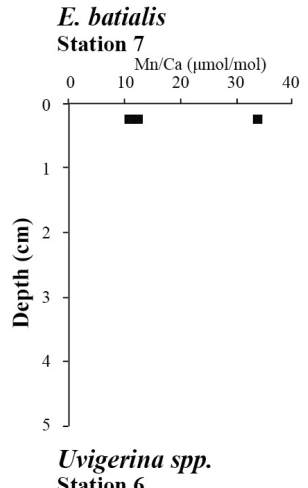

Station 8
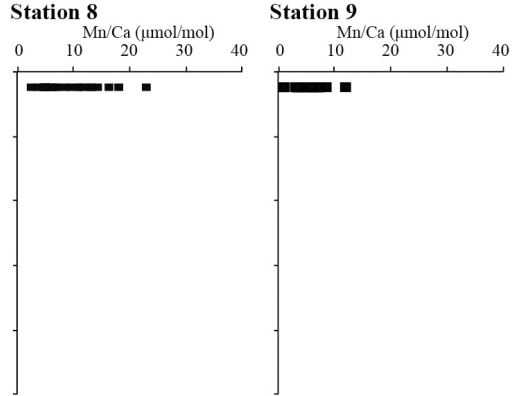

Station 6

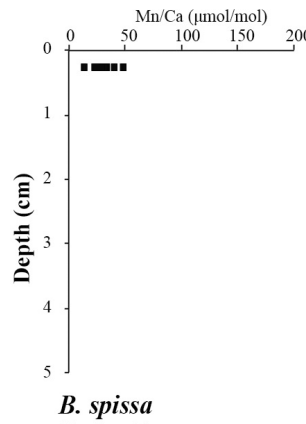

Station 7

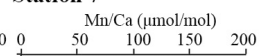

Station 8
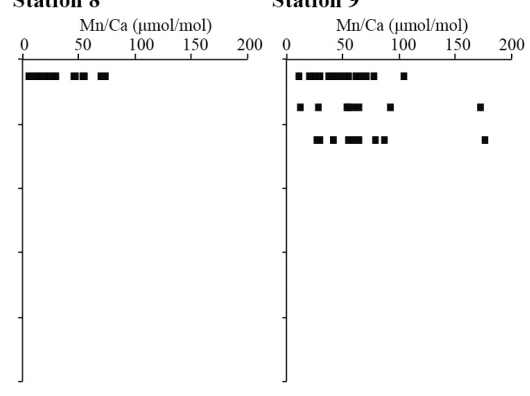

B. Spissa
Station 7

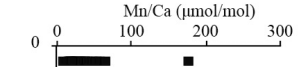

Station 8

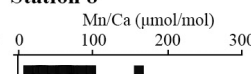

Station 9

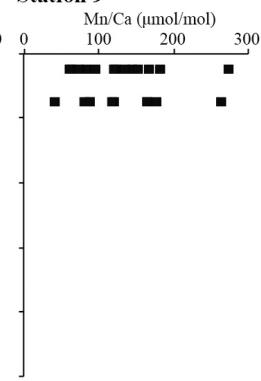

N. labradorica
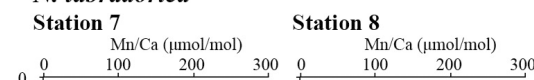

Station 10
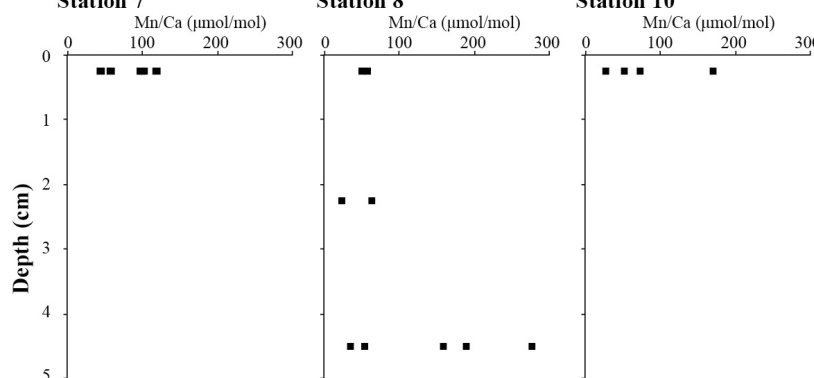

C. fimbriato

$$
\text { Station } 7
$$
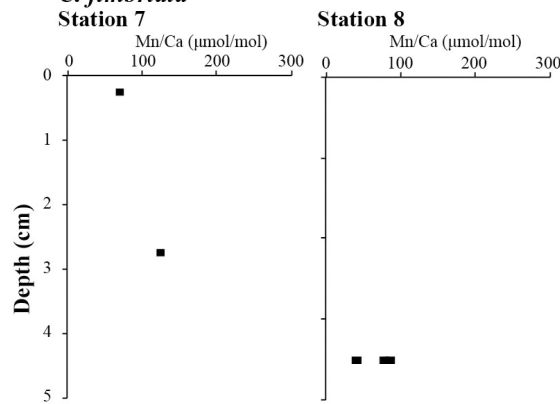

Station 9

tation 9

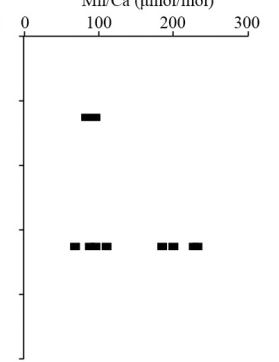

Figure 5. Individual laser ablation measurements of $\mathrm{Mn} / \mathrm{Ca}$ in foraminifera versus sediment depth where the specimens were collected. 

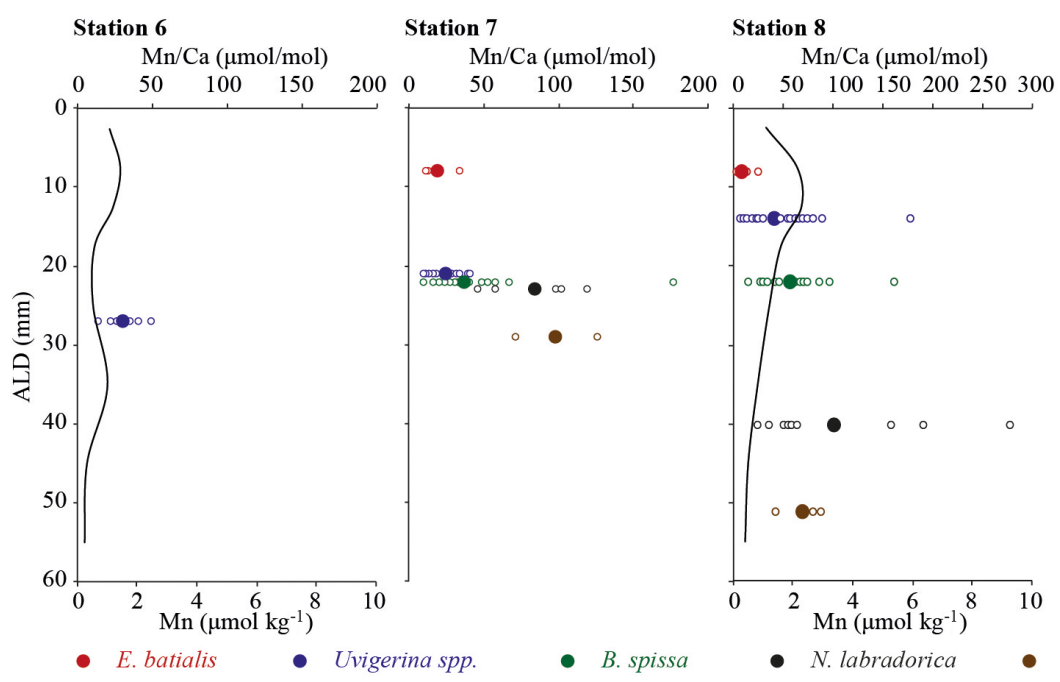
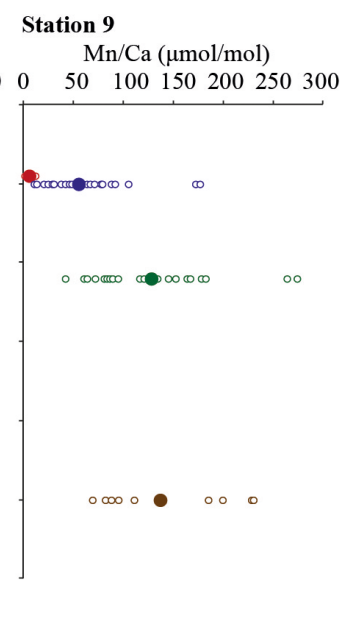

Station 10
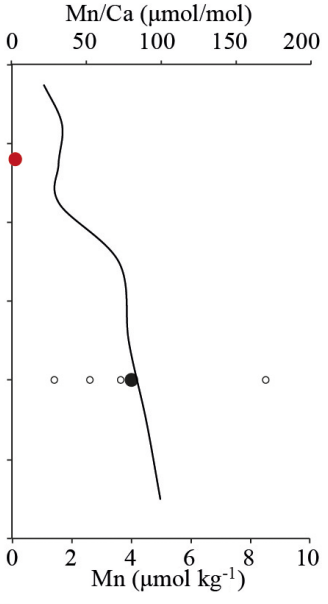

Figure 6. $\mathrm{Mn} / \mathrm{Ca}$ ratios in foraminifera as a function of the average living depth of each species. The average of all measurements is indicated by a solid symbol and the individual measurements by open symbols. In addition, the pore water profile of Mn is shown at all sites where it was measured.
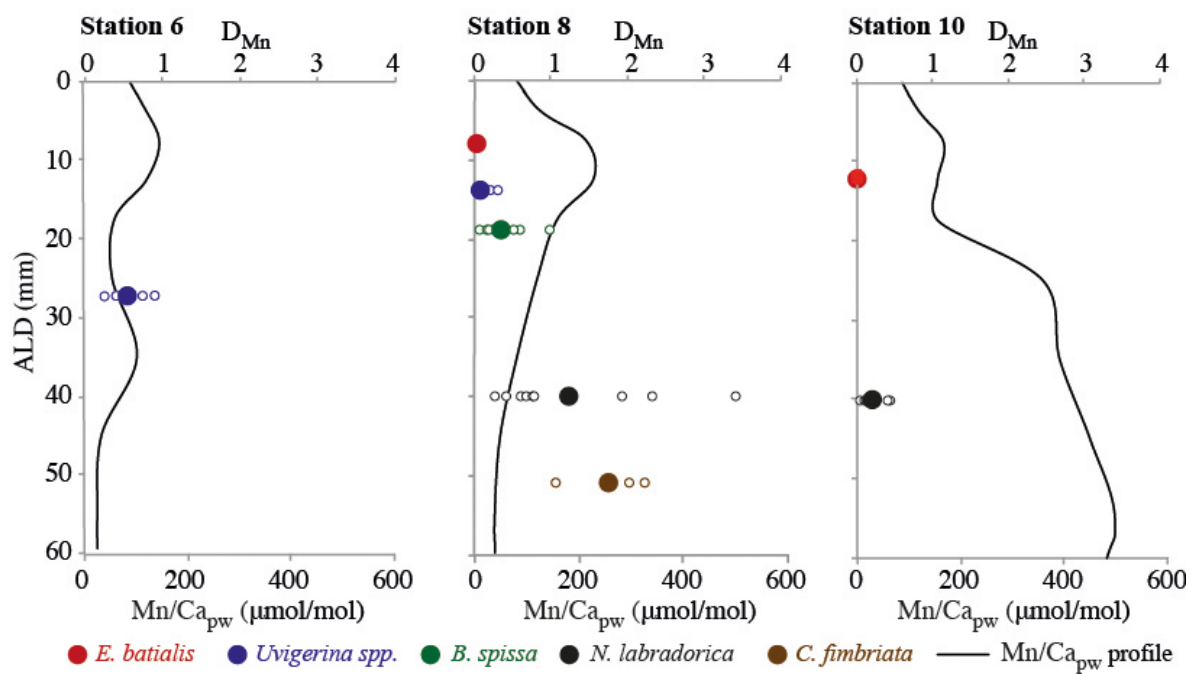

Figure 7. Manganese partition coefficient DMn in foraminifera as a function of average living depth of each species. In addition, the pore water (pw) Mn / Ca profile is shown.

\section{Discussion}

\subsection{Intrashell variability in Mn / Ca ratios}

Traditionally, $\mathrm{Mn} / \mathrm{Ca}$ in foraminiferal test carbonate is used to indicate the presence of diagenetic Mn oxyhydroxides and Mn carbonates (e.g. Boyle et al., 1983; Barker et al., 2003). However, studies applying techniques such as LA (laser ablation)-ICP-MS, allow circumventing surface contamination by a high depth resolution during the measurement (e.g. Hathorne et al., 2003; Reichart et al., 2003; Koho et al., 2015). In our study all measurements were also conducted with application of LA-ICP-MS; hence, all surficial Mn con- taminants were excluded from data. In addition, all specimens analysed here were stained with rose bengal, implying that they were alive, or very recently alive, when collected. Due to the nature of the specimens being very recent, the presence of any diagenetic coatings is unlikely and $\mathrm{Mn} / \mathrm{Ca}$ ratios reflect true $\mathrm{Mn}$ incorporation into the shell walls.

Another advantage of LA-ICP-MS is that it allows measurements of individual foraminiferal chambers, providing information on the changes in the elemental composition in relation to foraminiferal ontogeny or growth. In this study no systematic variations were noted in the $\mathrm{Mn} / \mathrm{Ca}$ ratios and chamber stages of any foraminifera (Fig. 4, Fig. S1). These observations are consistent with work of Dueñas- 

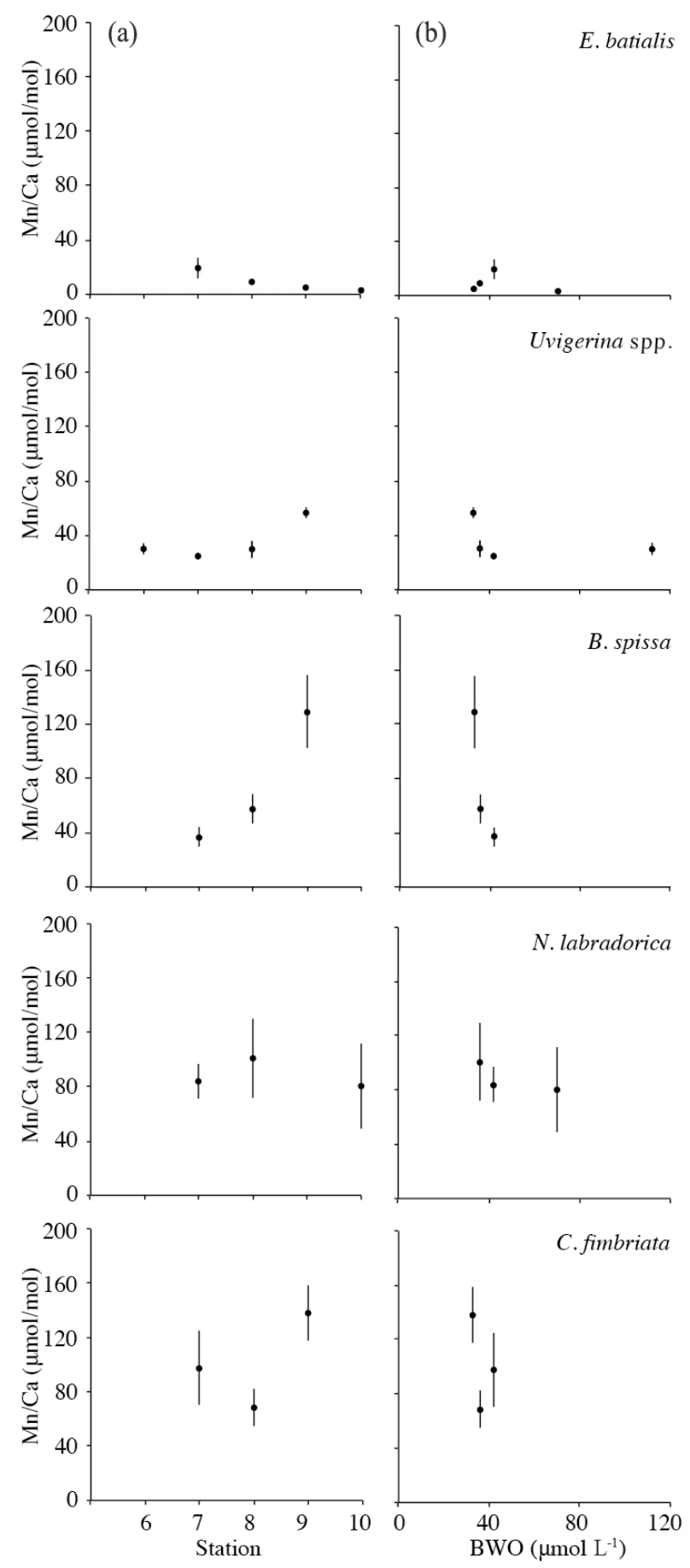

Figure 8. Variability in average Mn / Ca ratios of each species plotted against the study transect from station 6 to station 10 (a) and along the bottom water oxygenation (b). The error bars represent the standard error of the measurements.

Bohórquez (2010), who also noted no clear trend in the $\mathrm{Mn} / \mathrm{Ca}$ ratios with chamber stages of Cibicidoides pachyderma. Therefore, it appears that $\mathrm{Mn} / \mathrm{Ca}$ ratios in benthic foraminifera are not substantially influenced by ontogenetic processes, as it is occasionally reported for other elements, e.g. $\mathrm{Mg}$ and B (e.g. Raitzsch et al., 2011), but are primarily driven by environmental changes, such as redox conditions, affecting the concentration of $\mathrm{Mn}$ in pore waters. This implies that these foraminifera did not consistently calcify different chambers at different in-sediment depths, with contrasting Mn concentrations. Effectively this rules out systematic ontogenetic migration across oxygen gradients in the benthic foraminiferal species studied here.

\subsection{Mn / Ca ratios as a function of microhabitat}

Foraminifera from three microhabitats (shallow, intermediate and deep infauna) were included in this study (Fig. 6): $E$. batialis representing the shallow infaunal microhabitat, Uvigerina spp. and B. spissa representing the intermediate microhabitat, and $N$. labradorica and $C$. fimbriata representing the deep infaunal microhabitat. At all stations, the lowest $\mathrm{Mn} / \mathrm{Ca}$ ratios were measured in the shallow-dwelling E. batialis. In general, with deeper microhabitat distribution, the $\mathrm{Mn} / \mathrm{Ca}$ ratios appeared to increase (Fig. 6). The only exception seemed to be $C$. fimbriata at station 8 with the average $\mathrm{Mn} / \mathrm{Ca}$ ratio slightly lower than that of the other deep-infaunal taxa, $N$. labradorica. These results are in a good agreement with previous studies on foraminiferal $\mathrm{Mn} / \mathrm{Ca}$ ratios. In the Baltic Sea, for example, Groeneveld and Filipsson (2013) showed that specimens of the shallowdwelling Bulimina marginata were found to contain no or very small amounts of manganese in their carbonate test, whereas elevated $\mathrm{Mn} / \mathrm{Ca}$ ratios were measured in deep infaunal Globobulimina turgida. Moreover the results from the western Pacific presented here are in a good agreement with the TROXCHEM ${ }^{3}$ model, a conceptual three-dimensional model, linking foraminiferal Mn uptake, bottom water oxygenation and organic flux (Koho et al., 2015). Based on this model under relatively eutrophic conditions, where the bottom waters are still oxygenated, very low Mn concentrations are found in shallow infaunal species. Deeper in the sediment where higher concentrations of aqueous Mn are present in the pore water (namely station 10), an increase in foraminiferal $\mathrm{Mn} / \mathrm{Ca}$ is observed.

Pore water $\mathrm{Mn}$ profiles and $\mathrm{Mn} / \mathrm{Ca}$ ratios in foraminifera in combination with their ALD match relatively closely at station 6 and 10. At stations 6, pore water Mn concentrations were generally low; hence, the $\mathrm{Mn} / \mathrm{Ca}$ ratio in the Uvigerina spp. was also low. At station 10, where the greatest increase in the pore water Mn content was noted, the deep infaunal $N$. labradorica also showed much higher $\mathrm{Mn} / \mathrm{Ca}$ ratios than shallow-dwelling E. batialis. At station 8, however, where $\mathrm{Mn} / \mathrm{Ca}$ ratios peaked at just below $1 \mathrm{~cm}$ depth in sediment, the highest $\mathrm{Mn} / \mathrm{Ca}$ ratios were noted in N. labrador$i c a$, with an ALD of $4.0 \mathrm{~cm}$. The apparent mismatch between the pore water profiles and $\mathrm{Mn} / \mathrm{Ca}$ ratios in foraminifera from their ALD suggests that foraminifera may not always calcify at their observed ALD. As the foraminiferal ALDs represent the average depth where foraminifera are found, 
they may be skewed by a few individuals recovered from deeper or shallower depth intervals. In addition, bimodal distributions, which were seen for B. spissa at station 7 and Uvigerina spp. at stations 7 and 8 (Fontanier et al., 2014), can be considered problematic in the case of ALD calculations. However, this does not explain the discrepancy observed at station 8 as the modes of maximum density and ALD of $N$. labradorica were alike: 4.5 and $4.0 \mathrm{~cm}$, respectively.

Calculated Mn partitioning coefficients (based on pore water concentrations at ALDs) showed a large range in values, ranging from 0.02 for $E$. batialis to 1.77 for $C$. fimbriata. This could imply large offsets between ALD and calcification depths, but partition coefficients for Mn and other elements (e.g. $\mathrm{Mg}$ ) have also been shown to vary between species (e.g. Toyofuku et al., 2011; Wit et al., 2012; Koho et al., 2015). Previous field-based estimates suggest that the $D_{\mathrm{Mn}}$ for benthic foraminifera is generally close to 1 (Glock et al., 2012; Koho et al., 2015), whereas controlled growth experiments of Munsel et al. (2010) estimated that $\mathrm{Mn} / \mathrm{Ca}$ ratios could even be above 1, with 2.6-10 times higher ratios than in seawater. Irrespective of the observed differences in $D_{\mathrm{Mn}}$ values of the species coming from similar depth habitats, it seems that deep infaunal foraminifera, based on their Mn incorporation, are calcifying in or close to the pore waters where they were collected from. The shallow and intermediate infaunal species having $D_{\mathrm{Mn}}$ less than 1 based on their calculated ALD might calcify at a somewhat shallower depth where Mn concentrations are lower or actually have substantially lower $D_{\mathrm{Mn}}$ values.

Foraminifera are known to migrate in the sediment and laboratory experiments have shown that changes in the sediment oxygenation typically result in the migration of foraminifera to their preferred microhabitat (Gross, 2000; Geslin et al., 2004). Although, no systematic ontogenetic migration was seen in this study, foraminiferal migration is anticipated as all of the studied taxa were found in a relatively wider range of sediment depths (Fontanier et al., 2014). Therefore, foraminiferal migration may resolve some of the discrepancies seen in the foraminiferal $D_{\mathrm{Mn}}$ values and explain part of the discrepancies between the foraminiferal $\mathrm{Mn} / \mathrm{Ca}$ ratios and Mn pore water concentrations. Even relatively small-scale migration of intermediate and deep infaunal taxa could result in relatively large changes in the ambient pore water Mn content, which would be reflected in the test chemistry during calcification. Furthermore, a closer observation of $\mathrm{Mn} / \mathrm{Ca}$ ratios of sediment-dwelling foraminifera shows that both intermediate and deep infaunal species showed relatively higher range of $\mathrm{Mn} / \mathrm{Ca}$ values at each station (Figs. 4, 6). In contrast, the shallow-living E. batialis, which is expected to mainly inhabit the surficial, more oxygenated sediments, displayed relatively low variability. This suggests that the deeper habitat depth exposes foraminifera to greater variations in pore water Mn concentration. Alternatively, it should be noted that the foraminiferal $\mathrm{Mn} / \mathrm{Ca}$ measurements were carried out in a range of chambers, in- cluding younger and older ones (Fig. 4), whereas pore water profiles represent a snapshot in time. Therefore, some mismatch can be expected to result from variation in pore water conditions through time.

The relatively high $\mathrm{Mn}$ measured in deep infaunal foraminifera, and for B. spissa at station 9 only, further implies that these taxa actively grow in dysoxic sediments where pore water Mn concentrations are higher. Although not shown for the species studied here, foraminifera are known to be capable of denitrification (e.g. RisgaardPetersen et al., 2006; Piña-Ochoa et al., 2010a) and prolonged survival under anoxic conditions (Piña-Ochoa et al., 2010b). Therefore, it is very likely that the deep infaunal taxa studied here have also adapted to similar life strategies. Foraminiferal calcification in the absence of oxygen was also recently demonstrated by Nardelli et al. (2014), whose experimental approach demonstrated that three benthic foraminiferal species (Ammonia tepida, Bulimina marginata and Cassidulina laevigata) were not only able to survive under anoxic conditions but also to form new chambers. Here we show that Mn / Ca ratios in benthic foraminifera can also be measured to identify calcification under such conditions.

\subsection{Implications for palaeoceanographic reconstructions}

In recent years, efforts have been made to develop new bottom water oxygenation proxies via the application of foraminiferal $\mathrm{Mn} / \mathrm{Ca}$ ratios (Glock et al., 2012; Groeneveld and Filipsson, 2013; McKay et al., 2015; Koho et al., 2015). To date, direct statistically significant correlations between bottom water oxygenation and foraminiferal $\mathrm{Mn} / \mathrm{Ca}$ ratios have been noted only for the intermediate to deep infaunal M. barleeanus (Koho et al., 2015). In our study a statistically significant correlation between $\mathrm{Mn} / \mathrm{Ca}$ ratio and $\mathrm{BWO}$ was also measured in the intermediate infaunal foraminifera B. spissa (Pearson correlation coefficient: $-0.59, p<0.01, n=79$ ). Similarly in the study of Glock et al. (2012), Mn / Ca ratios measured in B. spissa from the Peruvian margin seemed to respond to BWO and associated changes in Mn redox chemistry, although the observed trend was not statistically significant. However, in the case of the other intermediate infaunal species studied here, namely Uvigerina spp., no robust statistical correlation with BWO was observed, although the highest $\mathrm{Mn} / \mathrm{Ca}$ ratios still coincided with the lowest BWO content $\left(33 \mu \mathrm{mol} \mathrm{L}^{-1}\right)$. Consistent with this observation, the highest $\mathrm{Mn} / \mathrm{Ca}$ ratios in Uvigerina peregrina from the Arabian Sea were measured at sites with BWO contents of $20-40 \mu \mathrm{mol} \mathrm{L}^{-1}$ (Koho et al., 2015). These observations give further confidence that intermediate infaunal species may be the most suitable proxies for BWO and redox reconstructions in the productivity regimes studied here and the study of Koho et al. (2015). Their suitability is most likely related to the vicinity of their microhab- 
itat to the zone of Mn reduction, leading to higher sensitivity for recording changes in redox conditions.

By contrast with intermediate infauna, no clear trends were observed along the study transect in the $\mathrm{Mn} / \mathrm{Ca}$ ratios of deep or shallow infaunal species (Fig. 8). The $\mathrm{Mn} / \mathrm{Ca}$ ratios were relatively, constantly low in shallow infaunal $E$. batialis or relatively high in deep infaunal species. In the case of the shallow infauna, the surficial microhabitat does not seem to expose foraminifera to pore water Mn, leading to the hampering of the any redox signal. Therefore, our data suggest that shallow infaunal taxa may not be suitable for the reconstruction of past redox conditions, in line with the results presented in Koho et al. (2015). However, the exact response of deep versus intermediate infauna to changes in bottom water oxygenation is most likely to depend on the intricate interplay with organic matter loading. Although productivity at our study site is anticipated to be relatively lower (annual average around $46 \mathrm{mmol} \mathrm{C}^{-1} \mathrm{~m}^{-2} \mathrm{~d}^{-1}$, Yokouchi et al., 2007) than in the northern Arabian Sea (annual average $111 \mathrm{mmol} \mathrm{C}^{-1} \mathrm{~m}^{-2} \mathrm{~d}^{-1}$, Barber et al., 2001), where the TROXCHEM ${ }^{3}$ model was developed, fluxes must still be relatively high, as shown by shallow nitrate penetration depth and relatively high ammonium content in the pore waters (Fig. 3). Therefore, influence on the intermediate infauna may also be anticipated here. However, if the carbon loading is lower, and subsequently Mn reduction occurs deeper in the sediment, an influence on deeper infauna may be more significant. In palaeo-studies where large changes in the carbon fluxes are foreseen, $\mathrm{Mn} / \mathrm{Ca}$ ratios in multiple species, including both intermediate and deep infaunal taxa, should be measured simultaneously.

Along the study transect, the total pore water Mn inventory did not correlate with BWO content (Fig. 3), having a direct implication for palaeoceanographic studies aiming to combine the two. In addition to sedimentary redox chemistry, the total potential pool of $\mathrm{Mn}$ in the pore water is related to the availability of $\mathrm{Mn}$ oxides in the sedimentary environments (e.g. Van der Weijden et al., 1999; Law et al., 2009). In this study both intermediate infaunal taxa (B. spissa and Uvigerina $\mathrm{spp}$.) showed consistent variability in their $\mathrm{Mn} / \mathrm{Ca}$ ratios along the study gradient (Fig. 8), with ratios increasing with water depth. Therefore, these trends are likely to reflect an increase in the pore water Mn along our study transects as also shown by the pore water Mn profiles (Fig. 3). Concentrations of $\mathrm{Mn}^{2+}$ were generally low at station 6, located at around $500 \mathrm{~m}$ water depth, where the maximum dissolved $\mathrm{Mn}^{2+}$ concentrations were only $1.4 \mu \mathrm{mol} \mathrm{L}{ }^{-1}$ at sediment depths of $0.75 \mathrm{~cm}$. With increasing water depth, both the total depth of the in-sediment zone containing elevated dissolved $\mathrm{Mn}^{2+}$ and total concentrations of dissolved manganese increased. At station 10, at a water depth of $2000 \mathrm{~m}$, relatively elevated pore water manganese concentrations were found at sediment depths between 2 and $10 \mathrm{~cm}$ with a maximum of $5.0 \mu \mathrm{mol} \mathrm{L}-1$, occurring at a sediment depth of $5.5 \mathrm{~cm}$. This pore water $\left[\mathrm{Mn}^{2+}\right]$ increase, which is also reflected in the foraminiferal $\mathrm{Mn}$ / Ca, may, in addition to bottom water oxygenation, also be related to an increase in $\mathrm{Mn}$ oxides in the sediment with increasing water depth. Such changes could be due to sustained Mn recycling, which, with no Mn escaping to the water column over time, results in the accumulation of high Mn oxides close to the sediment-water interface. Alternatively, manganese "shuttling", or downslope transport and focusing of Mn oxides, is well described in the literature (e.g. Schulz et al., 2013; Jilbert et al., 2013), typically explaining spatial differences in the distribution of solid-phase manganese along BWO gradients. The slightly higher BWO conditions at the deeper station might have allowed Mn being shuttled there. In addition, although BWO content was higher than $33 \mu \mathrm{mol} \mathrm{L}{ }^{-1}$ at all sites during our expedition, at some sites manganese may be able to escape the sedimentary environment at times, leading to relatively Mn-depleted pore waters. This may be the case especially at stations 6 and 8 , where the Mn reduction was taking place very close to the sediment surface at the time (Fig. 3). Moreover, kinetics of manganese oxidation are known to be relatively slow, and subsequently in some aqueous settings $\mathrm{Mn}^{2+}$ has been observed to penetrate into the overlying oxic water column in a metastable form (e.g. Balzer, 1982; Pakhomova et al., 2007), resulting in $\mathrm{Mn}^{2+}$ escaping the sedimentary system and diagenetic recycling. At station 10, where the highest pore water $\left[\mathrm{Mn}^{2+}\right]$ values are noted, Mn oxide reduction occurs well within the sediment (at depths of between 5 and $7 \mathrm{~cm}$ ). Thus, here the internal cycling of Mn (hydr)oxides is likely to be more efficient, resulting in $\mathrm{Mn}^{2+}$ being efficiently trapped within the system (Van der Weijden, 1999; Law et al., 2009). Palaeoceanographic reconstructions applying $\mathrm{Mn} / \mathrm{Ca}$ ratios as a proxy for changes in redox chemistry therefore need to take into account changes in the availability of Mn oxides, which could influence sediment biogeochemistry and the incorporation of $\mathrm{Mn}$ into foraminiferal test carbonate.

\section{Conclusions}

Here we show that Mn / Ca ratios in benthic foraminifera reflect their microhabitat distribution, with $\mathrm{Mn} / \mathrm{Ca}$ ratios increasing with deeper in-sediment habitat. Although appreciable differences between species in Mn partitioning were present, the overall higher $\mathrm{Mn} / \mathrm{Ca}$ measured in some intermediate and deep-infaunal foraminifera suggest that these taxa actively grow and calcify in dysoxic-anoxic sediments where pore water Mn concentrations are also higher. We also show that $\mathrm{Mn}$ incorporation into foraminiferal carbonate appears to reflect the ambient environmental conditions and is not influenced by ontogenetic processes. With regard to palaeoceanographic reconstructions, the application of $\mathrm{Mn} / \mathrm{Ca}$ ratios in intermediate infaunal foraminifera, such as $B$. spissa, which showed a statistically significant correlation between BWO and $\mathrm{Mn} / \mathrm{Ca}$, seems most promising, as their microhabitat appears to expose them to systematic 
and broad variations in pore water manganese in response to environmental changes.

Data availability. Datasets (raw data of measurements) are given in Table S1.

\section{The Supplement related to this article is available online at https://doi.org/10.5194/bg-14-3067-2017-supplement.}

Competing interests. The authors declare that they have no conflict of interest.

Acknowledgements. The authors would like to thank the captain and the crew of R/V Tansei Maru, as well as other cruise participants, for the execution of a successful research cruise. Hisami Suga is thanked for taking the bullet train and travelling from Tokyo to Hachinohe port just to supply correct vials and caps for pore water analyses. NWO-ALW (Earth and Life Sciences council) is acknowledged for funding the open competition research proposal "Trace metal incorporation in benthic foraminifera: linking ecology and pore water geochemistry" (grant number: 820.01.011). This work was also supported by the Academy of Finland (project number: 278827, 283453), JSPS KAKENHI (grant number: 25247085) and the Gravitation grant NESSC from the Dutch Ministry of Education, Culture and Science. Nina Keul and an anonymous reviewer are thanked for their comments, which significantly improved the previous version of this paper.

Edited by: Markus Kienast

Reviewed by: Nina Keul and one anonymous referee

\section{References}

Balzer, W.: On the distribution of iron and manganese at the sediment/water interface: thermodynamic versus kinetic control, Geochim. Cosmochim. Ac., 46, 1153-1161, 1982.

Barber, R. T., Marra, J., Bidigare, R. C., Codispoti, L. A., Halpern, D., Johnson, Z., Latasa, M., Goericke, R., and Smith, S. L.: Primary productivity and its regulation in the Arabian Sea during 1995, Deep-Sea Res. Pt. II, 48, 1127-1172, 2001.

Barker, S., Greaves, M., and Elderfield, H.: A study of cleaning procedures used for foraminiferal $\mathrm{Mg} / \mathrm{Ca}$ paleothermometry, Geochem. Geophy. Geosy., 4, 8407, https://doi.org/10.1029/2003GC000559, 2003.

Barnett, P. R. O., Watson, J., and Connelly, D.: A multiple corer for taking virtually undisturbed samples from shelf, bathyal and abyssal sediments, Oceanol Acta, 7, 399-408, 1984.

Boyle, E. A.: Manganese overgrowths on foraminifera tests, Geochim. Cosmochim. Ac., 47, 1815-1819, 1983.

Corliss, B. H.: Microhabitats of benthic foraminifera within deepsea sediments, Nature, 314, 435-438, 1985.

de Nooijer, L. J., Hathorne, E. C., Reichart, G.-J., Langer, G., and Bijma J.: Variability in calcitic $\mathrm{Mg} / \mathrm{Ca}$ and $\mathrm{Sr} / \mathrm{Ca}$ in clones of the benthic foraminifer Ammonia tepida, Mar. Micropaleontol., 107, 32-43, https://doi.org/10.1016/j.marmicro.2014.02.002, 2014.

Dueñas Bohórquez, A.: Geochemical and Biological Impacts on Trace and Minor Element Incorporation in Foraminiferal Test Carbonate, chap. 6, Changes in trace and minor element incorporation in the deep benthic foraminifera Cibicidoides pachyderma as a function of microhabitat and ontogeny, Geologica Ultraiectina, PhD thesis, Utrecht University, Utrecht, 320, 113-136, 2010.

Dueñas-Bohórquez, A., Raitsch M., de Nooijer L. J., and Reichart G.-J.: Independent impacts of calcium and carbonate ion concentration on $\mathrm{Mg}$ and $\mathrm{Sr}$ incorporation in cultured benthic foraminifera, Mar. Micropaleontol., 81, 122-130, 2011.

Elderfield, H., Yu, J., Anand, P., Kiefer, T., and Nyland, B.: Calibrations for benthic foraminiferal $\mathrm{Mg} / \mathrm{Ca}$ paleothermometry and the carbonate ion hypothesis, Earth Planet. Sc. Lett., 250, 633649, 2006.

Finney, B. P., Lyle, M. W., and Heath, G. R.: Sedimentation at MANOP site H (eastern Equatorial Pacific) over the past 400,000 years: climatically induced redox variations and their effects on transi tion metal cycling, Paleoceanography, 3, 169-189, 1988.

Fontanier, C., Duros, P., Toyofuku, T., Oguri, K., Koho, K. A., Buscail, R., Grémare, A., Radakovitch, O., Deflandre, B., De Nooijer, L. J., Bichon, S., Goubet, S., Ivanovsky, A., Chabaud, G., Menniti, C., Reichart, G.-J., and Kitazato, H.: Living (stained) deep-sea foraminifera off hachinohe (NE Japan, western Pacific): Environmental interplay in oxygen-depleted ecosystems, J. Foramin. Res., 44, 281-299, 2014.

Froelich, P. N., Klinkhammer, G. P., Bender, M. L., Luedtke, N. A., Heath, G. R., Cullen, D., Dauphin, P., Hammond, D., Hartman, B., and Maynard, V.: Early oxidation of organic matter in pelagic sediments of the eastern equatorial Atlantic: suboxic diagenesis, Geochim. Cosmochim. Ac., 43, 1075-1090, 1979.

Geslin, E., Heinz, P., Jorissen, F., and Hemleben, C.: Migratory responses of deep-sea benthic foraminifera to variable oxygen conditions: Laboratory investigations, Mar. Micropaleontol., 53, 227-243, 2004.

Glock, N., Eisenhauer, A., Liebetrau, V., Wiedenbeck, M., Hensen, C., and Nehrke, G.: EMP and SIMS studies on $\mathrm{Mn} / \mathrm{Ca}$ and $\mathrm{Fe} / \mathrm{Ca}$ systematics in benthic foraminifera from the Peruvian OMZ: a contribution to the identification of potential redox proxies and the impact of cleaning protocols, Biogeosciences, 9, 341359, https://doi.org/10.5194/bg-9-341-2012, 2012.

Groeneveld, J. and Filipsson, H. L.: Mg / Ca and Mn/Ca ratios in benthic foraminifera: the potential to reconstruct past variations in temperature and hypoxia in shelf regions, Biogeosciences, 10, 5125-5138, https://doi.org/10.5194/bg-10-5125-2013, 2013.

Gross, O.: Influence of temperature, oxygen and food availability on the migrational activity of bathyal benthic foraminifera: Evidence by microcosm experiments, Hydrobiologia, 426, 123-137, 2000.

Hathorne, E. C, Alard, O., James, R. H., and Rogers, N. W.: Determination of intratest variability of trace elements in foraminifera by laser ablation inductively coupled plasmamass spectrometry, Geochem. Geophy. Geosy., 4, 8408, https://doi.org/10.1029/2003GC000539, 2003.

Hathorne, E. C., James, R. H., Savage, P., and Alard, O.: Physical and chemical characteristics of particles produced by laser ab- 
lation of biogenic calcium carbonate, J. Anal. Atom. Spectrom., 23, 240-243, 2008.

Helder, W. and De Vries, R. T. P.: An automatic phenolhypochlorite method for the determination of ammonia in seaand brackish waters, Neth. J. Sea Res., 13, 154-160, 1979.

Itou, M., Matsumura, I., and Noriki, S.: A large flux of particulate matter in the deep Japan Trench observed just after the 1994 Sanriku-Oki earthquake, Deep-Sea Res. Pt. I, 47, 1987-1998, 2000.

Jilbert, T. and Slomp, C. P.: Iron and manganese shuttles control the formation of authigenic phosphorus minerals in the euxinic basins of the Baltic Sea, Geochim. Cosmochim. Ac., 107, 155169, 2013.

Jochum, K. P., Weis, U., Stoll, B., Kuzmin, D., Yang, Q., Raczek, I., Jacob, D. E., Stracke, A., Birbaum, K., Frick, D. A., Günther, D., and Enzweiler, J.: Determination of reference values for NIST SRM 610-617 glasses following ISO guidelines, Geostand. Geoanal. Res., 35, 397-429, 2011.

Jorissen, F. J., de Stigter H. C., and Widmark J. G. V.: A conceptual model explaining benthic foraminiferal microhabitats, Mar. Micropaleontol., 26, 3-15, 1995.

Keul, N., Langer, G., De Nooijer, L. J., Nehrke, G., Reichart, G.-J., and Bijma, J.: Incorporation of uranium in benthic foraminiferal calcite reflects seawater carbonate ion concentration, Geochem. Geophy. Geosys., 14, 102-111, https://doi.org/10.1029/2012GC004330, 2013.

Koho, K. A., García, R., de Stigter, H. C., Epping, E., Koning, E., Kouwenhoven, T. J., and van der Zwaan, G. J.: Sedimentary labile organic carbon and pore water redox control on species distribution of benthic foraminifera: a case study from LisbonSetúbal Canyon (southern Portugal), Prog. Oceanogr., 79, 55-82, 2008.

Koho, K. A. and Piña-Ochoa, E.: Benthic Foraminifera: Inhabitants of Low-Oxygen Environments, in: Cellular Origin, Life in Extreme Habitats and Astrobiology, edited by: Altenbach, A., Bernhard, J. M., and Seckbach, J., Anoxia: Evidence for Eukaryote Survival and Paleontological Strategies, 21, 249-285, https://doi.org/10.1007/978-94-007-1896-8, 2012.

Koho, K. A., de Nooijer, L. J., and Reichart, G.-J.: Combining benthic foraminiferal ecology and shell $\mathrm{Mn} / \mathrm{Ca}$ to deconvolve past bottom water oxygenation and paleoproductivity, Geochim. Cosmochim. Ac., 165, 294-306, 2015.

Law, G. T. W., Shimmield, T. M., Shimmield, G. B., Cowie, G. L., Breuer, E. R., and Martyn Harvey, S.: Manganese, iron, and sulphur cycling on the Pakistan margin, Deep-Sea Res. Pt. II, 56, 305-323, 2009.

McKay, C. L., Groeneveld, J., Filipsson, H. L., Gallego-Torres, D., Whitehouse, M. J., Toyofuku, T., and Romero, O. E.: A comparison of benthic foraminiferal $\mathrm{Mn} / \mathrm{Ca}$ and sedimentary $\mathrm{Mn} / \mathrm{Al}$ as proxies of relative bottom-water oxygenation in the low-latitude NE Atlantic upwelling system, Biogeosciences, 12, 5415-5428, https://doi.org/10.5194/bg-12-5415-2015, 2015.

Mezger, E. M., De Nooijer, L. J., Boer, W., Brummer, G. J. A., and Reichart, G. J.: Salinity controls on Na incorporation in Red Sea planktonic foraminifera, Paleoceanography, 31, 1562-1582, 2016.

Munsel, D., Kramar, U., Dissard, D., Nehrke, G., Berner, Z., Bijma, J., Reichart, G.-J., and Neumann, T.: Heavy metal incorporation in foraminiferal calcite: results from multi-element enrich- ment culture experiments with Ammonia tepida, Biogeosciences, 7, 2339-2350, https://doi.org/10.5194/bg-7-2339-2010, 2010.

Nagata, Y., Ohtani, K., and Kashiwai, M.: Subarctic Gyre in the North Pacific Ocean. Umi No Kenkyu, 1, 75-104, 1992 (in Japanese).

Nardelli, M. P., Barras, C., Metzger, E., Mouret, A., Filipsson, H. L., Jorissen, F., and Geslin, E.: Experimental evidence for foraminiferal calcification under anoxia, Biogeosciences, 11, 4029-4038, https://doi.org/10.5194/bg-11-4029-2014, 2014.

Nürnberg, D., Bijma, J., and Hemleben, C.: Assessing the reliability of magnesium in foraminiferal calcite as a proxy for water mass temperatures, Geochim. Cosmochim. Ac., 60, 803-814, 1996.

Oguama, S., Suzuki T., and Nagata, Y. Seasonal variations in the Sea of Sanriku Coast, Japan, J. Oceanogr., 58, 825-835, 2002.

Pakhomova, S. V., Hall, P. O. J., Kononets, M. Yu., Rozanov, A. G., Tengberg, A., and Vershinin, A. V.: Fluxes of iron and manganese across the sediment-water interface under various redox conditions, Mar. Chem., 107, 319-331, 2007.

Piña-Ochoa, E., Høgslund, S., Geslin, E., Cedhagen, T., Revsbech, N. P., Nielsen, L. P., Schweizer, M., Jorissen, F., Rysgaard, S., and Risgaard-Petersen, N.: Widespread occurrence of nitrate storage and denitrification among Foraminifera and Gromiida, P. Natl. Acad. Sci. USA, 107, 1148-1153, 2010a.

Piña-Ochoa, E., Koho, K. A., Geslin, E., and Risgaard-Petersen, N.: Survival and life strategy of foraminifer, Globobulimina turgida, through nitrate storage and denitrification, Mar. Ecol.-Prog. Ser., 417, 39-49, 2010b.

Raitzsch, M., Hathorne, E. C., Kuhnert, H., Groeneveld, J., and Bickert, T.: Modern and late pleistocene B / Ca ratios of the benthic foraminifer Planulina wuellerstorfi determined with laser ablation ICP-MS, Geology, 39, 1039-1042, 2011.

Reichart, G.-J., Jorissen, F., Anschutz, P., and Mason, P. R. D.: Single foraminiferal test chemistry records the marine environment, Geology, 31, 355-358, 2003.

Risgaard-Petersen, N., Langezaal, A. M., Ingvardsen, S., Schmid, M. C., Jetten, M. S. M., Op Den Camp, H. J. M., Derksen, J. W. M., Piña-Ochoa, E., Eriksson, S. P., Nielsen, L. P., Revsbech, N. P., Cedhagen, T., and van der Zwaan, G. J.: Evidence for complete denitrification in a benthic foraminifer, Nature, 443, 93-96, 2006.

Saino, T., Shang, S., Mino, Y., Suzuki, K., Nomura, H., Saitoh, S.-I., Miyake, H., Masuzawa, T., and Harada, K.: Short term variability of particle fluxes and its relation to variability in sea surface temperature and chlorophyll a field detected by Ocean Color and Temperature Scanner (OCTS) off Sanriku, northwestern North Pacific in the spring of 1997, J. Oceanogr., 54, 583-592, 1998.

Schulz, F., McManus, J., and Sommer, S.: The manganese and iron shuttle in a modern euxinic basin and implications for molybdenum cycling at euxinic ocean margins, Chem. Geol., 355, 56-68, 2013.

Toyofuku, T., Suzuki, M., Suga, H., Sakai, S., Suzuki, A., Ishikawa, T., de Nooijer, L. J., Schiebel, R., Kawahata, H., and Kitazato, H.: $\mathrm{Mg} / \mathrm{Ca}$ and $\delta^{18} \mathrm{O}$ in the brackish shallow water benthic foraminifer Ammonia beccarii, Mar. Micropaleontol., 78, 113120, 2011.

Van der Weijden, C. H., Reichart, G. J., and Visser, H. J.: Enhanced preservation of organic matter in sediments deposited within the oxygen minimum zone in the northeastern Arabian Sea, DeepSea Res. Pt. I, 46, 807-830, 1999. 
Wit, J. C., de Nooijer, L. J., Barras, C., Jorissen, F. J., and Reichart, G. J.: A reappraisal of the vital effect in cultured benthic foraminifer Bulimina marginata on $\mathrm{Mg} / \mathrm{Ca}$ values: assessing temperature uncertainty relationships, Biogeosciences, 9, 36933704, https://doi.org/10.5194/bg-9-3693-2012, 2012.

Yokouchi, K., Tsuda, A., Kuwata, A., Kasai, H., Ichikawa, T., Hirota, Y., Adachi, K., Asanuma, I., and Ishida H.: Chapter 3 simulated in situ measurements of primary production in Japanese waters, Elsevier oceanography series, 73, 65-88, 2007.
Yu, J. and Elderfield, H.: Benthic foraminiferal B / Ca ratios reflect deep water carbonate saturation state, Earth Planet. Sc. Lett., 258, 73-86, 2007.

Yu, J., Foster, G. L., Elderfield, H., Broecker, W. S., and Clark, E.: An evaluation of benthic foraminiferal B / Ca and $\delta^{11} \mathrm{~B}$ for deep ocean carbonate ion and $\mathrm{pH}$ reconstructions, Earth Planet. Sc. Lett, 293, 114-120, 2010. 